\title{
MİRAS SÖZLEŞMELERİNDE AŞIRI YARARLANMANIN UYGULANABİLİRLİĞİ
}

DOI: https://doi.org/10.33717/deuhfd.787610

\section{Dr. Barış DEMIRSATAN}

\begin{abstract}
Öz
Aşırı yararlanmanın bulunmaması borçlar hukukuna tabi, tam iki taraflı sözleşmelerin geçerlilik koşulları arasındadır. MK m. 5 hükmü uyarınca aşırı yararlanmanın miras sözleşmelerinde uygulanması mümkün gözükmekte ise de konu, daha kapsamlı bir değerlendirme yapılmasını gerektirmektedir. Miras sözleşmesi kurulurken bir tarafin zor durumda olması, düşüncesizlikle hareket etmesi veya deneyimsiz olması mümkündür. Karşı tarafin da bu durumdan yararlanmak suretiyle sömürü kasdı bulunabilir. Miras sözleşmeleri bakımından aşırı yararlanmada özellik arz eden durum, karşılıklı kazandırmalar arasındaki açık oransızlığın belirlenmesidir. Karşılıklı kazandırma gerekliliği nedeniyle aşırı yararlanmanın uygulanması sadece ivazlı veya iki taraflı miras sözleşmelerinde söz konusu olabilir. Ancak mirasçı atanan tarafindan kazanılacak miras hakkının tutarı terekenin mirasın açılma anındaki durumuna bağlı olacağından mirasçı atama tasarrufu; mirasbırakanın sağlararası işlem yapma ve tasarruf olană̆ını ortadan kaldırmadı̆̆ından vasiyet birakma tasarrufu oransızlık açısından değerlendirme yapılmaya elverişli sayılamaz. Başka bir deyişle muhataralı işlem sayıldıkları için aşırı yararlanmaya yol açamazlar. Aşırı yararlanma hükmünün uygulanabilmesi için değerlendirme yapmaya elverişli kazandırmalar, kural olarak miras sözleşmesindeki sağlararası kazandırma ile çeşit ve tedarik vasiyetleridir. Aşır yararlanma sebebi ile miras sözleşmesinin iptal edilmesi bu itibarla sinırl hallerde söz konusu olabilir. Buna karşılık miras sözleşmesinin kuruluş tarzı nedeniyle ahlaka aykırılıktan bahisle hükümsüz sayılması ihtimal dâhilindedir. Ayrıca miras bırakanın veya sağlararası kazandırmada bulunanın culpa in contrahendo sorumluluğu da doğabilir.
\end{abstract}

İstanbul Üniversitesi Hukuk Fakültesi, Medeni Hukuk Anabilim Dalı Araştırma Görevlisi (e-posta: baris.demirsatan@istanbul.edu.tr) ORCID: https://orcid.org/00000002-0228-5236 (Makalenin Geliş Tarihi: 03.05.2020) (Makale Gönderilme Tarihi: 04.05.2020/Makale Kabul Tarihi: 02.06.2020) 


\author{
Anahtar Kelimeler \\ Miras sözleşmesi, Aşırı yararlanma, Mirasçı atama, Vasiyet, \\ Kazandirmalar arasinda denge
}

\title{
SUSCEPTIBILITY OF INHERITANCE CONTRACTS TO UNFAIR ADVANTAGE
}

\begin{abstract}
Lack of unfair advantage is among the validity conditions of bilateral contracts subject to the law of obligations. As per article 5 of the Turkish Civil Code, it seems possible to apply the provision against unfair advantage in inheritance contracts, but this subject requires a more comprehensive evaluation. When concluding an inheritance contract, it is possible for one party to be in a difficult situation, to act thoughtlessly or to be inexperienced. The other party may also have the intention to exploit such situation. The problematic concerning inheritance contracts is the determination of disproportionality between reciprocal considerations. Due to the necessity of reciprocal considerations, the unfair advantage can only applied to bilateral inheritance contracts or inheritance contracts with consideration. Naming of heir and legacy cannot be deemed eligible for evaluation as the amount of inheritance to be acquired depends on the status of the estate at the time of inheritance and as the legacy does not prevent the testator from disposing his/her property. In other words, the aforementioned dispositions cannot lead to unfair advantage since they are aleatory transactions. The only considerations suitable for such evaluation are the inter-vivos considerations in the inheritance contract and the genus and supply legacies. In very limited cases, cancellation of the inheritance contract by virtue of unfair advantage is possible. On the other hand, it is possible for the inheritance contract to be deemed null due to the immorality in its way of conclusion. In addition, culpa in contrahendo responsibility may arise for the contractors.
\end{abstract}

\section{Keywords}

Inheritance contract, Unfair advantage, Naming of heir, Legacy, Balance between performance and consideration 


\section{GíRiş}

Türk Borçlar Kanununda benimsenen terimle aşırı yararlanma ${ }^{1}$, tam iki tarafa borç yükleyen sözleşmeler için TBK m. 28 uyarınca öngörülmüş, içeriği ahlaka aykırılığa ${ }^{2}$ sonuçları ise irade bozukluklarına yaklaşan ${ }^{3}$ bir hukuki olgudur. Varlığı sözleşmenin geçerliliğini etkiler. Bu açıdan sözleşme özgürlüğünün sınırlarından birini oluşturur ${ }^{4}$. Aşırı yararlanmaya karşı

818 sayılı Borçlar Kanununda aşırı yararlanma, m. 21 hükmünde "Gabin" kenar başlığ ile düzenlenmekteydi. 6098 sayılı Türk Borçlar Kanununda hukuk dilinin arılaştırılması çerçevesinde "Aşırı Yararlanma" terimi benimsenmiştir. Bu terim, kanımızca, kurumu açıklamaya yeterlidir. Unutmamak gerekir ki gabinin de sözlük anlamı aldatmaktır (Feyzioğlu, Feyzi N.: Borçlar Hukuku Genel Hükümler, C. I, İstanbul, 1976, s. 248; Sungur, Hasan Halis: Gabin, İstanbul, 1953, s. 15) ve düzenlenen kurumu doğrudan doğruya ifade etmekten uzaktır. Karş. Barlas, Nami: "Türk Borçlar Kanunu'nun Gabine İlişkin Yeni Düzenlemesinin Değerlendirilmesi”, Medeni Kanun'un ve Borçlar Kanunu'nun 90. Yılı Uluslararası Sempozyumu, C. I, Ankara, 2017, s. 372, yazar aşırı yararlanmayı anlamsız bir ifade olarak görmekte olup en azından "Sömürü" ifadesinin kullanılabileceğini belirtmektedir. Ayrıca benzer yönde: Akıncı, Şahin: Borçlar Hukuku Bilgisi, Konya, 2016, s. 106.

2 BK-Kramer, Ernst A.: Berner Kommentar Band/Nr. VI/1/2/1a, Bern, 1991, Art. 21 OR, N. 6; Ataay, Aytekin: Borçlar Hukukunun Genel Teorisi-Birinci Yarım, İstanbul, 1981, s. 277. Nitekim Alman hukukunda aşırı yararlanma, Al. MK §138 II hükmünde özel bir ahlaka aykırılık hali olarak düzenlenmiş ve kesin hükümsüzlük yaptırımına bağlanmıştır. Aşırı yararlanmanın, irade bozukluğu oluşturmadığı hususunda: Barlas, s. 369; Aslan, Çiğdem Mine: Gabinin Unsurları ve Hukuki Sonuçları, Ankara, 2006, s. 59; Acabey, M. Beşir: "Aşırı Yararlanma (TBK m. 28)", MÜHF-HAD Özel Hukuk Sempozyumu Özel Sayısı (Prof. Dr. Cevdet Yavuz'a Armağan), 2012, s. 107. Aksi yönde: Birsen, Kemaleddin: Borçlar Hukuku Dersleri, İstanbul, 1967, s. 85; Akıncı, s. 106, yazar iradenin oluşumunda bozukluğun gerçekleştiğini kabul etmektedir. Benzer görüşte: CR-Leuba, Audrey: Commentaire Romand Code Civil II Art. 457-977 CC, Basel, 2016, Art. 469 CC, N. 43. İrade bozukluğu olarak kabul eden görüşün temelinde kilise hukukunun bulunduğu hakkında: Morin, Anne: Contribution à l'étude des contrats aléatoires, Paris-Dauphine (Paris-IX) Üni. Doktora Tezi, Paris, 1995, N. 551.

3 Barlas, s. 370. Zira gerek aşırı yararlanmada gerekse irade bozukluklarında sözleşme iptal edilebilirlikle maluldür. Her iki iptal nedeni bakımından iptal hakkının etkisi hususunda (bozulabilir geçerlilik/düzelebilir hükümsüzlük) öğretide tartışma bulunmaktadır. Bu konuda bkz. Kocayusufpaşaoğlu, Necip: Borçlar Hukuku Genel Bölüm I, İstanbul, 2014, §39 N. 27; Nomer, Haluk N.: "Aşırı Yararlanma (Gabin) Halinde Sömürülen, Kendisine Tanınan Haklardan Dilediğini Seçmekte Tamamen Serbest Midir?”, Prof. Dr. Hasan Erman'a Armağan, İstanbul, 2015, s. 638-639. Ayrıca: Aydın, Ramazan: “Aşıırı Yararlanma (TBK m. 28), Erciyes Üniversitesi Hukuk Fakültesi Dergisi C. 8 S. 1 (Haziran 2013), s. 98; Tiftik, Mustafa: "Borç Sözleşmelerinin İrade Sakatlığı Sebebiyle İptalinde Uğranılan Zararın Tazmini”, Erzincan Üniversitesi Hukuk Fakültesi Dergisi C. 10 S. 3-4 (2006), s. 413-414.

4 Von Tuhr, Andreas/Peter, Hans: Allgemeiner Teil des Schweizerischen Obligationenrechts Band I (mit Supplement), 3. Bask1, Zürih, 1984, §40 I, s. 343; 
koruma, TBK m. 28 ile borçlar hukukuna tabi tam iki taraflı sözleşmelere ilişkin olarak öngörülmüş olsa da MK m. 5 hükmüne dayalı olarak miras sözleşmeleri ${ }^{5}$ bakımından da söz konusu olup olmayacağı hususunda açıklık

Saymen, Ferit H./Elbir, Halid K.: Türk Borçlar Hukuku Umumi Hükümler, İstanbul, 1958, s. 230; Kocayusufpaşaoğlu, $\S 39$ N. 2; Feyzioğlu, s. 249; Acabey, s. 107; Topuz, Murat: "Yargıtay Kararları Işığında Türk Borçlar ve Ticaret Hukukunda Gabin (Aşırı Yararlanma)", MÜHF-HAD, Özel Sayı: Doç. Dr. Mehmet Somer'in Anısına Armağan, 2006, s. 749; Yarg. HGK., 22.11.2018, 13-636/1762 (Kazanc1) "Tarafların karş1lıklı edimleri tayin edebilme konusundaki özgürlüklerine getirilmiş olan sınırlamalardan biri 6098 Sayılı Türk Borçlar Kanunu'nda "aşırı yararlanma" olarak adlandırılan, yürürlük tarihi itibari ile somut olayda uygulanması gereken BK'daki anlatımı ile "gabin" hâlidir." Aşırı yararlanmanın hukuki niteliğine ilişkin tartışmalar için: Okumuş, Selmani: 6098 sayılı Türk Borçlar Kanunu'na Göre Aşırı Yararlanma (Gabin), Ankara, 2015, s. 62 vd.; Çakırca, Seda İrem: Aşırı Yararlanma Kavramı, İstanbul, 2015, s. 25 vd. Dengesizlik itibarıyla sözleşmenin içeriği, karşı tarafın sömürü kastı itibarıyla irade oluşumuyla ilgili bir sınırlama olduğu: Huguenin, Claire: ObligationenrechtAllgemeiner und Besonderer Teil, Zürih, 2014, N. 452; Hem sözleşme özgürlüğü sınırlaması hem irade bozukluğu unsurları taşıdığı şeklinde: CHK-Kut, Ahmet: Handkommentar zum Schweizer Privatrech- Obligationenrecht - Allgemeine Bestimmungen, Zürih, 2016, Art. 21 OR, N. 1; Dürüstlük kuralının somutlaşması görüşü: BK-Hausheer, Heinz/Abbi-Müller, Regina E.: Berner Kommentar Band/Nr. I/1, Bern, 2012, Art. 2 ZGB, N. 75. Bu gerekçeyle daha sınırlayıcı olarak yorumlanması gerektiği yönünde: CHK-Kut, Art. 21 OR, N. 7; Bucher, Eugen: Schweizerisches Obligationenrecht Allgemeiner Teil ohne Deliktsrecht, Zürih, 1988, s. 228; IFM, 13.10.2005, 4C.238/2004 (Swisslex); Yarg. 17. HD., 19.2.2018, 14196/1061 (Kazanc1) "Oysa; kural olarak irade özerkliği ve sözleşme serbestisi içinde imzalandığı kabul edilmesi gereken ibranamelerin, müzayaka halinde imzalandığı iddiası ile geçersiz kılınmak istendiği; bu biçimde geçersizliği sağlayarak bunun sonuçlarından yararlanacak olan ve istisnai bir yol olan gabinin hukuksal sonuçlarından yararlanmak isteyen davacı taraf iddiasının doğru olup olmadığının araştırılması gerektiği açıktır. "Aksi yönde: BK-Kramer, Art. 21 OR, N. 7; Gauch, Peter/Schluep, Walter R./Schmid, Jörg: Schweizerisches Obligationenrecht Allgemeiner Teil Bd. I, Zürih, 2008, N. 748. Karş. Buz, Vedat: "Gabin Halinde Edimler Arasındaki Aşırı Oransızlığın Giderilerek Sözleşmenin Ayakta Tutulması", Banka ve Ticaret Hukuku Dergisi C. 19 S. 4 (Aralık 1998), s. 60, yazar aşırı yararlanmaya karşı öngörülen koruma ile irade özgürlüğünün korunduğunu belirtmektedir. Benzer yönde: Esener, Turhan/Gündoğdu, Fatih: Borçlar Hukuku I, İstanbul, 2017, s. 173.

5 Vasiyetnameler ve miras sözleşmesinin tek yanlı içeriğini oluşturan ölüme bağlı tasarruflarda "karşılıklılık" söz konusu olmadığından aşırı yararlanmanın gerçekleşmesi kavramsal olarak mümkün değildir. Serozan, Rona/Engin, B. İlkay: Miras Hukuku, Ankara, 2014, §4 N. 61; Dural, Mustafa: Miras Sözleşmeleri, İstanbul, 1980, s. 288; Atlı, Banu: Ölüme Bağlı Tasarrufların Hükümsüzlügü ve Hükümden Düşmesi, Ankara, 2017, s. 177; Başoğlu, Başak: "Miras Hukuku Özelinde Haksız Etkileme Kavramı ve Buna Bağlanabilecek Sonuçlar", Galatasaray Üniversitesi Hukuk Fakültesi Dergisi 2018/1, s. 407. Miras hukukuna ilişkin hükümlerde aşırı yararlanmaya yer verilmemesinin nedeninin, yasa koyucunun vasiyetnameyi esas alması olduğu hakkında: 
yoktur ${ }^{6}$. Öğretide çoğunlukla, miras sözleşmelerinde aşırı yararlanma nedeniyle iptale başvurulabileceği ifade ediliyor ${ }^{7}$ olsa da, bu konu miras sözleşmesinin içeriğine göre daha ayrıntılı olarak incelenmelidir.

\section{ASSIRI YARARLANMA KAVRAMI}

Türk hukuk sistemi sözleşenler arasındaki edimlerin dengesine kural olarak sınırlama getirmemiştir. Serbest piyasa ve müzakere ortamı çerçevesinde taraflar edim dengesini belirlemekte özgürdür. Bununla birlikte, edim-karşı edim dengesinin tamamen göz ardı edilmesi de mümkün değildir. Böylece, aşırı yararlanmaya ilişkin TBK m. 28 hükmü ile edimler arasındaki

Serozan/Engin, §4 N. 61. Aşırı yararlanmanın, tam iki taraflı olmayan sözleşmelere de uygulanabileceğini kabul eden görüş (Gauch/Schluep/Schmid, N. 735; Esener/ Gündoğdu, s. 174 dn. 134; Tek tarafa borç yükleyen sözleşmeler istisnasıyla: BKKramer, Art. 21 OR, N. 11) açısından bu yönden bir engel ölüme bağlı tasarruflarda da olmamalıdır.

6 Şunu belirtmek gerekir ki MK m. 5'in varlığı, aşırı yararlanmanın bütün hukuki işlemlere uygulanabileceği anlamına gelmez. Aşırı yararlanma, kavramsal olarak ilgili hukuki işlemin bünyesine uygun olmalıdır. Örnek olarak, tasarruf işlemleri doğrudan doğruya aşırı yararlanma nedeniyle hükümsüz olamaz (Ergüne, M. Serkan: Taşınır Mülkiyeti, İstanbul, 2017, N. 365). Ancak tasarruf işlemine sebep oluşturan hukuki işlem, aşırı yararlanmadan etkilenebilir. Bu durumda söz konusu hukuki işlem iptal edildiği takdirde tasarruf işlemi, sebebe bağlı olup olmamasına göre hükümsüzleşebilir veya sebepsiz zenginleşme teşkil edebilir. Karş. Wieling, Hans Josef: Sachenrecht, Heidelberg, 2007, $\S 1$ III $3 \mathrm{c}$ aa, s. 14, yazar tasarruf işlemlerinin geçerliliğinin de aşırı yararlanma hali de dâhil olmak üzere amaçtaki ahlaka aykırılık nedeniyle doğrudan etkileneceğini kabul etmektedir.

7 Serozan/Engin, §4 N. 61; Antalya, O. Gökhan: Mirastan Feragat Sözleşmesi, İstanbul, 1999, s. 231; Turan, Gamze: Ölüme Bağlı Tasarrufların Hükümsüzlüğü, Ankara, 2009, s. 72, yazar salt ivazlı miras sözleşmelerinde olanak tanımaktadır; İmre, Zahit: Türk Miras Hukuku, İstanbul, 1978, s. 329, yazar ivazlı miras sözleşmelerinde buna olanak vermektedir; Sağlam, İpek: "Haksız Etki”, MÜHF-HAD Özel Sayısı Prof. Dr. Mehmet Somer'in Anısına Armağan, Cilt: 12, Say1: 1-3, İstanbul, 2006, s. 691, yazar haksız etkileme olarak tanımladığı hallerde hiffetin geniş yorumlanmasıyla aşırı yararlanmaya başvurma olanağının yaratılabileceğini ancak aşırı yararlanmanın haksız etkiyi tamamen kapsamadığını belirtmektedir; Benzer şekilde: Başoğlu, s. 407, yazar haksız etkilemede aşırı yararlanma hükümlerinin tam olarak uygulanabilmesinin güç olduğunu ifade etmektedir. Haksız etkileme halinde aşırı yararlanmaya örneksemeyle başvurulmayacağ 1 yönünde karş.: CR-Leuba, Art. 469 CC, N. 44. Ayrıca: CHK-Kut, Art. 21 OR, N. 2; SHK- Roussianos, Leila/Auberson, Géraldine: Commentaire du droit des successions, Bern, 2012, Art. 469 CC, N. 6; İFM, 25.5.2000, 5C.91/2000 (Swisslex); Piotet, Paul: Traité de Droit Privé Suisse T. IV: Droit Successoral, Friburg, 1975, s. 201 ve 204; CRAbbet, Stéphane: Intro. Art. 494-497 CC, N. 24. Olumsuz miras sözleşmesinde: Antalya, Feragat, s. 231; Bıçakçı, Levent: Mirastan Feragat Sözleşmesi, İstanbul, 1999, s. 109; İmre, s. 311; Atlı, s. 178. 
aşırı bir oransızlığın sözleşmenin geçerliliğine etki edebileceği kabul edilmiştir ${ }^{8}$. Ayrıca, oransızlığın yüksek derecede gerçekleștiği birtakım hallerde, TBK m. 27 hükmüne ahlaka aykırılık gerekçesiyle başvurmak günümüzün toplumsal ve ekonomik gerçeklerine uygun ve haklı bir çözüm olarak benimsenmektedir?.

Aşırı yararlanma, edimler arası açık oransızlıktan kaynaklandığı için tanımı itibarıyla tam iki taraflı sözleşmelere özgüdür ${ }^{10}$. Edimler arasındaki

8 Cansel, Erol/Özel, Çağlar: Borçlar Hukuku Genel Hükümler Cilt-1, Ankara, 2017, N. 470; Erdoğan, İhsan: Borçlar Hukuku Genel Hükümler, Ankara, 2017, s. 85.

9 Von Tuhr/Peter, §40 II, s. 345; Kocayusufpaşaoğlu, §39 N. 34-35; Serozan, Rona: "Karşılıklı Sözleşmelerde Baştan Dayatılmış veya Sonradan Oluşmuş Edimler Arası Dengesizliğin Uyarlama Yoluyla Düzeltilmesi”, Prof. Dr. Kemal Oğuzman'ın Anısına Armağan, İstanbul, 2000, s. 1020; Aslan, s. 61; Ayrıca: Tercier, Pierre/Pichonnaz, Pascal/Develioğlu, H. Murat: Borçlar Hukuku Genel Hükümler, İstanbul, 2016, N. 856; Ateş, Derya: Borçlar Hukuku Sözleşmelerinde Genel Ahlaka Aykırılık, Ankara, 2007, s. 247; CHK-Kut, Art. 19-20 OR, N. 27; Aksi yönde: Bucher, s. 258-259; Gauch/ Schluep/Schmid, N. 756; OFK-Dasser, Felix: Orell Füssli Kommentar (Navigator.ch)Schweizerisches Obligationenrecht, Zürih, 2016, Art. 19 OR, N. 11; BK-Kramer, Art. 21 OR, N. 8. Hukukta çift etki kuramı kabul edilmezse, ahlaka aykırılık nedeniyle doğan kesin hükümsüzlük, aşırı yararlanmaya başvurmaya engel olur: Antalya, O. Gökhan: Borçlar Hukuku, C. I, İstanbul, 2015, s. 346; Kurşun, Ali Suphi: Aşırı Yararlanma ve Ahlaka Aykırılıkta Taleplerin Yarışması", İstanbul Kültür Üniversitesi Hukuk Fakültesi Dergisi C. 15 S. $2-2$ (Temmuz/Ağustos 2016), s. 207-208. Buna cevaz veren görüş: Von Tuhr/Peter, $\S 40$ II, s. 346 dn. 13e; Kocayusufpaşaoğlu, $\$ 39$ N. 34, §37 N. 29-30; Sungur, s. 39; Engel, s. 306; CR-Schmidlin, Bruno: Commentaire Romand Code des Obligations I, Basel, 2012, Art. 21 CO, N. 25; OFK-Dasser, Art. 21 OR, N. 6; Saymen/ Elbir, s. 244; Elbir, Halid Kemal: Türk Pozitif Hukukunda Gabin, IÜHF Doktora Tezi, 1957, s. 263; Ayrıca: Yarg. 14. HD., 8.5.2012, 2453/6534 (Kazanc1) "Sözleşmede, davaya konu dört adet taşınmazdaki davalının miras hak ve hisselerinin tamamının 1000 TL (1 milyar) bedel karşılığında davacıya satışının vaat edildiği ve bedelin ödendiği yazılıdır. Sözleşmenin yapıldığı 21.04.2004 tarihinden sonra davalı Yahyalı Noterliğinin 10.05.2004 tarihli 1256 yevmiye numaralı fesih ihtarı ile sözleşmeyi feshettiğini bildirmiştir. Dolayısıyla, Borçlar Kanununun 21. maddesinde öngörülen bir senelik süre içinde akitten dönen davalı, koşulların bulunması halinde gabin iddiasına da dayanarak sözleşmenin iptalini isteyebilir."; İsviçre Federal Mahkemesi de bir kararında bu olasılığa değinmekle birlikte konu hakkında net bir değerlendirme yapmamıştır: JdT 1970 I 92.

10 Kocayusufpaşaoğlu, $\$ 39$ N. 10; Tekinay, S. Sulhi/Akman, Sermet/Burcuoğlu, Haluk/Altop, Atilla: Borçlar Hukuku Genel Hükümler, İstanbul, 1993, s. 458; Sarı, Suat: "6098 sayılı Türk Borçlar Kanunu'nun Aşırı Yararlanma (Gabin) Hükümlerinde Gerçekleştirdiği Değiş̧iklikler”, Prof. Dr. Mustafa Dural'a Armağan, İstanbul, 2013, s. 1029; Engel, Pierre: Traité des obligations en droit suisse, Bern, 1997, s. 298; Belen, Herdem: 6098 sayılı Borçlar Kanunu Genel Hükümler (Kısa Şerh), İstanbul, 2014, s. 101. Ancak karş. Gauch/Schluep/Schmid, N. 735; CHK-Kut, Art. 21 OR, N. 2; IFM, 4A_479/2010 (Swisslex); BK-Kramer, Art. 21 OR, N. 11. 
aşırı dengesizlik ${ }^{11}$, aşırı yararlanmanın nesnel unsurunu oluşturmakla birlikte, aşırı yararlanmanın gerçekleşebilmesi için iki ayrı öznel unsurun da bulunması gereklidir ${ }^{12}$. Şöyle ki edimler arası dengesizlik, dengesizlik nedeniyle mağdur olan tarafın maddi veya manevi müzayakasından, düşüncesizliğinden ${ }^{13}$ yahut deneyimsizliğinden ileri gelmelidir ve karşı tarafin bu durumdan yararlanmaya yönelik sömürü kastı bulunmalıdır ${ }^{14}$. Bu çerçevede aşırı yararlanma, serbest piyasanın denetlenmesi ve düzenlenmesi amacına yönelik değildir, genel olarak edim-karşı edim dengesinin bozukluğu aşırı yararlanma aracillı̆ 1 ile giderilemez ${ }^{15}$.

11 Hangi ölçüde oransızlığın açık sayılacağı hususunda: Kocayusufpaşaoğlu, §39 N. 7-8; Tekinay/Akman/Burcuoğlu/Altop, s. 459; Cansel/Özel, N. 475 dn. 523; Antalya, Borçlar Hukuku, s. 347; Sungur, s. 27.

12 Yarg1 kararlarında öncelikle nesnel unsurun inceleneceği, bu koşul sağlanırsa öznel unsurların değerlendirileceği yönünde bir eğilim bulunsa da bu unsurlar arasında herhangi bir öncelik sonralık yoktur. Örnek olarak, Yarg. 1. HD., 21.6.2018, 2254/11408 (Kazanc1) "Hemen belirtmek gerekir ki gabin davasında öncelikle edimler arasındaki, aşırı oransızlık üzerinde durulmalı, objektif unsur ispatlandığı takdirde zarar gördüğünü iddia edenin kişiliği, yaşı, sağlık durumu, toplumdaki yeri, ekonomik gücü psikolojik yapısı gibi maddi, manevi yönler yani sübjektif unsur derinliğine araştırılıp incelenmelidir."; Yarg. 1. HD., 14.3.2019, 6631/1911 (Kazanc1); Yarg. 11. HD., 18.10.2001, 6087/8020 (Kazanc1).

13 Yarg. 1. HD., 28.3.2009, 1815/3343 (Kazanc1) "Dosya içeriği ve toplanan delillerden, özellikle Adli Tıp Kurumu raporu ile bu raporda atıf yapılan doktor raporlarından, davacının akit tarihinde hukuki ehliyeti haiz bulunduğu belirlenmişse de aşırı alkol düşkünlüğ̈̈ nedeniyle beyin fonksiyonlarında ve muhakeme yeteneğinde önemli ölçüde azalma meydana geldiği, davalının da davacısının kiracısı olması nedeniyle bu durumu bilebilecek konumda bulunduğu anlaşılmaktadır. ... Somut olayda edimler arasındaki aşırı oransızlık keşfen saptanmıştır. Bunun yanında, davacının düşüncesizlik halinin tüm delillerle açıklığa kavuştuğu ve kiracısı olan davalının da davacının da bu durumundan faydalandığı gözetildiğinde "gabin"in tüm unsurlarının gerçekleştiği sonucuna varılmaktadir."

14 Von Tuhr/Peter, $\$ 40$ I, s. 344; Kocayusufpaşaoğlu, $\$ 39$ N. 4; Nomer, Haluk N.: Borçlar Hukuku Genel Hükümler, İstanbul, 2020, N. 70.1-70.3; Huguenin, N. 454. Açık oransızlığın bariz ve aleni olması gerektiği: CR-Schmidlin, Art. 21 CO, N. 5; Von Tuhr/Peter, $\S 40$ I, s. 343 dn. 3. Ağır ihmal halinde de örneksemeyle aşırı yararlanmanın uygulama alanı bulabileceği fikrinde: OFK-Dasser, Art. 21 OR, N. 5; CHK-Kut, Art. 21 OR, N. 19. Açık oransızlı̆̆ın belirlenmesi bakımından hüküm içi boşluğun söz konusu olduğu görüşünde: BK-Emmenegger, Susan/Tschentscher, Axel: Einleitung, Art. 1-9 ZGB, 2012, Art. 1, N. 368 dn. 926. Oransizlığın taraflarca bilinmesinin gerekli olmadığı görüşünde: İnan, Ali Naim/Yücel, Özge: Borçlar Hukuku Genel Hükümler, Ankara, 2014, s. 240; Topuz, s. 755. Bununla birlikte sömürü kastı taşıan taraf, muhatabın durumundan istifade etme maksadını taşımak zorundadır: Kocayusufpaşaoğlu, $\S 39$ N. 21.

15 Kocayusufpaşaoğlu, $\S 39$ N. 12. 
Aşırı yararlanmanın yukarıda belirtilen koşulları gerçekleştiği takdirde, sözleşme iptal edilebilirlik ile malul olur ${ }^{16}$. Başka bir deyişle aşırı yararlanmanın bulunmaması tam iki taraflı sözleşmeler açısından bir geçerlilik şartıdır ${ }^{17}$. Aşırı yararlanmanın sözleşmenin kuruluş şekli ile ilgili olması ve bir tarafın sömürülmesine karşı öngörülmüş olmasına rağmen, bu durum ahlaka aykırılık ile eşdeğer sayılmamış; daha uygun bir yaptırım olarak iptal edilebilirlik öngörülmüştür. Bu durumda sömürüye uğrayan taraf, durumun özelliğine göre ${ }^{18}$ işlemi iptal edebilir veya iptal yerine edimler arasındaki oransızlığın giderilmesini $^{19}$ isteyebilir $^{20}$. Aşırı yararlanma, sözleşmenin

16 Sadece oransızlığı ortadan kaldırma hakkının tanınmayıp iptal hakkının öngörülmüş olması, hukuken yaptırıma bağlananın aşırı oransızlık değil ahlaka aykırı sömürü kasdının olduğunu gösterir: Nomer, Aşırı Yararlanma, s. 646.

17 Oğuzman, M. Kemal/Barlas, Nami: Medeni Hukuk, İstanbul, 2018, N. 716; Elbir, s. 151 .

18 Aşırı yararlanmaya maruz kalanın birincisi bozucu diğeri değiştirici iki seçimlik yenilik doğuran hakkının bulunduğu, durumun özelliğinden seçim hakkının MK m. 2'ye uygun kullanılması gerektiğinin anlaşılması hususunda: Barlas, s. 377-378; Nomer, N. 70.970.10; Sarı, s. 1037; Acabey, s. 113. Bu çerçevede TBK m. 27/II c. 2'den de yararlanılabileceği görüşü: Nomer, Aşırı Yararlanma, s. 648. Karş. Hâkime değişiklik yapma yetkisi veren görüş: Oğuzman, M. Kemal/Öz, Turgut: Borçlar Hukuku Genel Hükümler, C. I, İstanbul, 2018, N. 433; Antalya, Borçlar Hukuku, s. 352; Aksoy Dursun, Sanem: "Sözleşmenin İçeriği; Sözleşmelerin Yorumu, Muvazaalı İşlemler", Prof. Dr. İsmet Sungurbey’e Armağan: Borçlar Hukuku Genel Hükümler Konferansları I, İstanbul, 2014, s. 116.

19 Bunun kısmi iptal anlamına geldiği: Erdoğan, s. 88; Akıncı, s. 109; Antalya, Borçlar Hukuku, s. 351; Aydın, s. 101. Kısmi iptalle oluşan sözleşme boşluğunun da doldurulduğu: Nomer, N. 70.9; Değiştirilmiş kısmi hükümsüzlük şeklinde: Sarı, s. 1034. Nitekim 818 sayılı Kanun döneminde ve İsviçre'de de açık hüküm olmasa dahi, bu sonuca kısmi hükümsüzlük kavramıyla ulaşılacağı kabul görmekteydi: Von Tuhr/Peter, $\S 40$ II, s. 346; BK-Kramer, Art. 21 OR, N. 49; Engel, s. 305; OFK-Dasser, Art 21 OR, N. 1; JdT 1998 I 568; Gauch/Schluep/Schmid, N. 754; Schwenzer, Ingeborg: Schweizerisches Obligationenrecht Allgemeiner Teil, Bern, 2016, N. 32.55; Bucher, s. 234 vd.; Nomer, Aşırı Yararlanma, s. 639; Tercier/Pichonnaz/Develioğlu, N. 842; CRSchmidlin, Art. 21 CO, N. 18 vd.; İnan/Yücel, s. 245; Buz, s. 64 vd.; Kılıçoğlu, Ahmet M.: Borçlar Hukuku Genel Hükümler, Ankara, 2018, s. 304; Okumuş, s. 176 vd.; Çakırca, s. 208 vd.; Aslan, s. 128 vd.

20 Yasa koyucu, aşırı yararlanmayı TBK m. 27'ye tabi tutmuş olsaydı bile, amaca uygun sınırlama ile yine yürürlükteki iptal yaptırımının uygulanması gerekirdi. Zira bu durumda amaç, aşırı yararlanmaya maruz kalanı korumaktır. Eğer, kesin hükümsüzlük yaptırımı doğrudan uygulansaydı, edimler arasındaki dengesizliğin giderilmesi söz konusu olamazdı ve özellikle zor durumda kalmaktan kaynaklanan aşırı yararlanmada, gereksinim duyulan edimi zor durumdaki taraf iade etmek zorunda kalırdı. Bu yönde değerlendirilebilir: Schwarz, Andreas B.: Borçlar Hukuku Dersleri, (Çeviri: Bülent Davran), İstanbul, 1948, s. 352; İptal edilebilirlik yaptırımının yerindeliği: Feyzioğlu, s. 
geçerliliği ile ilgili bir unsur olduğu için sözleşmenin kurulduğu an itibaryyla koşulları dikkate alınır ${ }^{21}$. Edimler dengesini etkileyen sonraki durum değişiklikleri işlem temelinin çökmesi kurumu çerçevesinde değerlendirilmek gerekir ${ }^{22}$.

\section{MİRAS SÖZLEŞMESININ GEÇERLILİK KOŞULLARI BAKIMINDAN AŞIRI YARARLANMANIN UYGULAMA ALANI}

Aşırı yararlanma, tam iki tarafa borç yükleyen sözleşmeler için öngörülmüş olsa da $\mathrm{MK} \mathrm{m}$. 5 hükmü uyarınca bu kurumun miras sözleşmelerine uygulanabilirliği değerlendirilmelidir. Zira ölüme bağlı tasarruflar, kendilerine özgü bir geçersizlik rejimine tabidir ${ }^{23}$. Hükümsüzlük nedenleri ve hükümsüzlüğün sonuçları, genel hükümlere tabi işlemlerden büyük ölçüde ayrılmaktadır. Ehliyetsizlik, irade bozuklukları, hukuka veya ahlaka ayk1rılık ${ }^{24}$ ile şekle aykırılık iptal edilebilirlik yaptırımına bağlanmıştır (MK m.

262; Ataay, s. 260; Tunçomağ, Kenan: Türk Borçlar Hukuku Cilt 1 Genel Hükümler, İstanbul, 1976, s. 393-394; Nomer, Aşırı Yararlanma, s. 645; Belen, s. 103; Gauch/ Schluep/Schmid, N. 747.

21 Huguenin, N. 451; Kocayusufpaşaoğlu, §39 N. 9; Tercier/Pichonnaz/Develioğlu, N. 845; İnan/Yücel, s. 238; Feyzioğlu, s. 251; Tunçomağ, Genel Hükümler, s. 381; Kılıçoğlu, s. 301; Oğuzman/Öz, N. 427; Sungur, s. 20; Okumuş, s. 97; Çakırca, s. 135; Aslan, s. 68; Schwenzer, N. 32.50; Engel, s. 302; Saymen, Ferit Hakk1: "Gabinde İvazlar Arasındaki Nisbetsizlik", İÜHFM C. 11 S. 3-4 (1945), s. 149; Yarg. 4. HD., 18.1.1958, 6713/283 (Kazanc1) "Borçlar Kanununun 21. maddesinde gabinin kanuni şartlarından olduğu bildirilen karşılıklar arasındaki aşırı nisbetsizlik durumunun bir hadisede bulunup bulunmadığını tesbit için akitten sonraki iktisadi veya kanuni şartlardaki değişikliklerle meydana gelecek fiyat dalgalanmaları esas tutulmayıp akdin yapıldığı tarih itibariyle tarafların birbirlerine sağlayacakları menfaatlerin değerleri esas tutulmak zaruridir."

22 Engel, s. 302; Bucher, s. 231 dn. 13; CR-Schmidlin, Art. 21 CO, N. 3. Bu durumda, farklı bir tartışma olarak miras sözleşmelerinde işlem temeli çökmesinin uygulanabilirliği değerlendirilmek gerekecektir. Uygulanabileceği hususunda: Baysal, Başak: Sözleşmenin Uyarlanması, İstanbul, 2019, N. 391; CR-Leuba, Art. 469 CC, N. 43; BSK-Breitschmid, Art. 469 ZGB, N. 12; Olumsuz miras sözleşmesinde: CR-Abbet, Art. 494 CC, N. 6.

23 Serozan, Rona: Sağlararası İşlem Yoluyla Ölüme Bağlı Kazandırma, İstanbul, 1979, s. 23; İmre, s. 313 vd.; Oğuzman, M. Kemal: Miras Hukuku, İstanbul, 1995, s. 185; Serozan/Engin, §4 N. 28; CR-Piotet, Denis: Art. 519/520 CC, N. 1. Karş. Tek yaptırımın iptal edilebilirlik olduğu şeklinde: İşgüzar, Hasan/Demir, Mehmet/Yılmaz, Süleyman: Miras Hukuku, Ankara, 2019, s. 36.

24 Hukuka veya ahlaka aykırılık halinde, MK m. 557/b. III hükmüne karşın, uygulanacak yaptırım tartı̧malıdır. İptal edilebilirlik yönünde: Oğuzman, s. 186; Serozan/Engin, §4 
$557)^{25}$. Kanunda özellikle irade bozukluklarına iptal sebebi olarak yer verilirken aşırı yararlanmanın düzenlenmesinden kaçınılması yasa koyucunun bilinçli olarak sustuğu fikrini akla getirebilir. Buna karşılık aşırı yararlanmanın bir geçersizlik sebebi olarak kabul edilmesine dayanak oluşturan gerekçeler, kuramsal olarak miras sözleşmeleri bakımından da söz konusu olabilir. Bu nedenle, genel bir ifadeyle, ölüme bağlı tasarruflara kendine özgü ve kapalı bir geçersizlik rejimi öngörüldüğü gerekçesiyle, aşırı yararlanmanın MK m. 5 atfiyla uygulanmayacağı ileri sürülemez ${ }^{26}$. Bu durumda, aşırı yararlanma, irade bozukluklarıyla aynı sonuca yol açacak şekilde bir iptal sebebi teşkil edebilir. Öte yandan miras sözleşmesinde ölüme bağlı tasarrufta bulunmayan taraf için geçerlilik koşulları genel hükümlere tabidir. $\mathrm{Bu}$ itibarla iki taraflı olmayan miras sözleşmelerinde geçerlilik rejiminde bir asimetri bulunacağı ifade edilebilirr ${ }^{27}$. Bir taraf açısından ölüme bağlı tasar-

N. 72; Gönensay, Samim/Birsen, Kemaleddin: Miras Hukuku, İstanbul, 1963, s. 70; Eren, Fikret: Türk Medeni Hukukunda Ölüme Bağlı Tasarrufların İptali Davası, Ankara, 1966, s. 47. Karş1 görüş ise bu durumda örtülü boşluğun varlığından bahisle kesin hükümsüzlüğün gerçekleşmesini kabul etmektedir: Kocayusufpaşaoğlu, Necip: Miras Hukuku, İstanbul, 1987, s. 337; Dural, s. 280; Akkanat, Halil: Ölümün Özel Hukuk İlişkilerine Etkisi, İstanbul, 2004, s. 15 dn. 42; Turan, s. 82; Antalya, O. Gökhan/Sağlam, İpek: Miras Hukuku, Ankara, 2019, N. 1147; Ayrıca: SHK-Cotti, Art. 494 CC, N. 22; BSK-Forni, Rolando/Piatti, Giorgio: Art. 519/520 ZGB, N. 4; Kamu düzeni ve kişilik hakları açısından: CR-Piotet (D.), Art. 519/520 CC, N. 11, hukuka aykırılıkta: N. 18. Olması gereken hukuk açısından kesin hükümsüzlük yaptırımının daha uygun olduğu: İnan, Ali Naim/Ertaş, Şeref/Albaş, Hakan: Türk Medeni Hukuku Miras Hukuku, İzmir, 2012, s. 283. Amaçta hukuka ve ahlaka aykırılıkta iptal, konuda aykırılıkta kesin hükümsüzlük görüşü: Hatemi, Hüseyin: Miras Hukuku, İstanbul, 2018, $\S 6 \mathrm{~N}$. 29-30. Bu hususta kanımızca ölüme bağlı tasarrufun, başlangıçtaki objektif imkânsızlıkla birlikte hukuka ve ahlaka aykırılık hallerinde kesin hükümsüz sayılması görüşü üstün tutulmalıdır. Mirasbırakanın son arzuları, hukuk düzeninin ve fizik kurallarının önünde olmadığı gibi kanuna veya ahlaka aykırı edimlerin ifa ve icrasına da sırf ölüme bağlı tasarrufa konu oldukları gerekçesiyle olanak tanınmamalıdır.

25 İnan/Ertaş/Albaş, s. 276; Oğuzman, s. 187 vd.; Dural/Öz, s. 226 vd.; Çabri, Sezer: Miras Hukuku Şerhi Cilt 1 (TMK m. 495-574), İstanbul, 2018, N. 1297 vd. Ölüme bağlı tasarrufta bulunanın, irade bozukluğu nedeniyle ölüme bağlı tasarruftan dönebileceğine ilişkin MK m. 504 hükmü ile tasarrufta bulunanın irade bozukluğunun sağlığındaki etkisi düzenlenmiştir.

27 SHK-Cotti, Art. 494 CC, N. 8; Eren, İptal, s. 91; Turan, s. 97; CR-Leuba, Art. 469 CC, N. 7; Ehliyet açısından: CR-Leuba, Art. 468 CC, N. 24; Bıçakçı, s. 97; Eren, İptal, s. 26; Kocayusufpaşaoğlu, Miras Hukuku, s. 146; Dural, s. 75; Atlı, s. 92; Çabri, N. 290; CR-Abbet, Intro. Art. 494-497 CC, N. 28; Druey, Jean Nicolas: Grundriss des Erbrechts, Bern, 2002, s. 160; BK-Weimar, Peter: Berner Kommentar Band/Nr. III/1/1/1- Schweizerisches Zivilgesetzbuch, Das Erbrecht, Die Erben, Die gesetzlichen 
ruflara ilişkin hükümler uygulanırken diğer taraf açısından genel hükümler geçerli olur.

Esas olarak incelenmesi gereken, aşırı yararlanmanın unsurları itibarıyla miras sözleşmelerine uygulanabilir olup olmadığıdır. Miras sözleşmelerinde öznel unsurların gerçekleşmesi bakımından herhangi bir engel olmayacaktır. Her iki taraf da sömürü kastı taşıyabileceği gibi işlemi yaparken zor durum $^{28}$, düşüncesizlik veya deneyimsizlik içinde olabilir. Aşırı yararlanmanın miras sözleşmesine uygulanabilirliği açısından incelenmesini gerektiren husus, edimler arası açık oransızlıktır ${ }^{29}$.

Son olarak belirtmek gerekir ki, karma bağışlama kavramı çerçevesinde kurulan ölüme bağlı karma bağışlama sözleşmeleri veya kısmen ivazsız kısmen ivazlı miras sözleşmeleri aşırı yararlanma hükümlerine tabi tutu$\operatorname{lamaz}^{30}$. Zira bu işlemlerde, karşılıklı kazandırmalar arasındaki dengesizlik, bir tarafın karşı tarafin zor durumda olmasından, deneyimsizliğinden veya düşüncesizliğini sömürü kasdından ileri gelmez. Başka bir deyişle karşılıklı kazandırmalar içeren bir sözleşmede, kazandırmalar arasında açık bir oransızlık bulunuyorsa, bu durum aşırı yararlanmanın öznel unsurlarından kaynaklanmıyor aksine tarafların serbest, sıhhatli, hukuka ve ahlaka uygun iradelerinden kaynaklanıyorsa işlemin geçerliliğini etkilenmez. Nitekim karma bağışlama kavramı, bu olanağın varlığından kaynaklanmaktadır.

Erben, Die Verfügungen von Todes wegen, Bern, 2009, Art. 468 ZGB, N. 23; Escher, Arnold: Zürcher Kommentar Art. 457-536 ZGB, 1959, Art. 468 ZGB, N. 10. İrade bozukluğunda: Dural, s. 271; Atll, s. 113; Tuor, Peter: Berner Kommentar zum schweizerischen Zivilgesetzbuch Band III Das Erbrecht, Bern, 1952, Art. 469 ZGB, N. 3. Miras sözleşmesinde sağlararası işlem yapan tarafın da ölüme bağlı tasarrufta bulunan tarafla aynı rejime tabi olması gerektiği görüşünde: Piotet, s. 260-261; CR-Piotet (D.), Art. 519/520 CC, N. 60.

Darda kalmak olarak anlaşılması gerektiği: Barlas, s. 374; Eren, Fikret: Borçlar Hukuku Genel Hükümler, Ankara, 2019, N. 1294; 818 sayılı Kanun döneminde: Tunçomağ, Genel Hükümler, s. 384.

29 Karş. Yakupoğlu, S. Derya: Olumlu Miras Sözleşmesi ve Bağlayıcılık Sorunu, Bilkent Üni. Ekonomi ve Sosyal Bilimler Enstitüsü Doktora Tezi, Ankara, 2019, s. 228-229, yazar ölüme bağlı ve sağlararası kazandırmanın somut niteliklerine değinmeksizin edimler arası açık oransızlığın gerçekleşmeyeceğini kabul ettikten sonra örnekseme ile uygulanabileceğini kabul etmektedir. Kanımızca oransızlığın söz konusu olmadığı bir aşırı yararlanma mümkün değildir. Bu olasılıkta ancak, aşağıda açıklanacağı üzere ahlaka aykırılık nedeniyle hükümsüzlük gerçekleşebilir.

30 Bu kavramlar için: Akbıyık, Cem: Karma Bağışlama ve Miras Hukukundaki Yeri, İstanbul, 1997, s. 51-53. 


\section{AŞIRI YARARLANMADA KARŞILIKLI KAZANDIRMA- LARIN VARLIĞI AÇISINDAN SINIRLAMA}

Miras sözleşmesinde, mirasbırakanın yaptığı bağlayıc1 ${ }^{31}$ ölüme bağlı tasarruf karşılığında diğer taraf sağlararası bir borç altına giriyorsa, sözleşme ivazlıdır $^{32}$. Buna karşılık sağlararası borç altına giren bir taraf yoksa miras sözleşmesi ivazsızdır ${ }^{33}$. Miras sözleşmesinde her iki taraf da miras sözleşmesinin bağlayıcı içeriğini oluşturan nitelikte ölüme bağlı tasarrufta bulunuyorsa $^{34}$, iki taraflı miras sözleşmesi söz konusu olur ${ }^{35}$. Bu sözleşme, Medeni Kanun anlamında ivazlı miras sözleşmesi olarak nitelendirilemez. Tek taraflı miras sözleşmelerinde ise ölüme bağlı tasarrufta taraflardan sadece biri bulunur $^{36}$. Bu itibarla, miras sözleşmesinin ivazlılığı ve iki veya tek taraflı olması birbirinden bağımsız hususlara bağlı durumdadır.

Tek taraflı ivazsız miras sözleşmelerinde aşırı yararlanmanın uygulama alanı bulamayacağ 1 açıktır ${ }^{37}$. Sadece bir taraf ölüme bağlı tasarrufta bulunurken karşı taraf sadece mirasbırakanın irade beyanını kabul etmektedir. $\mathrm{Bu}$ itibarla sözleşmenin iki tarafi arasında açık oransızlık oluşturabilecek karşılıklı bir kazandırma yoktur.

31 CHK-Hrubesch-Millauer, Stephanie: Handkommentar zum Schweizer PrivatrechtErbrecht, Zürih, 2016, Art. 494 ZGB, N. 3.

32 Dural, s. 50; İmre, s. 279; Çabri, N. 760; İnan/Ertaş/Albaş, s. 255; Oğuzman, s. 133134.

33 Dural, s. 49; İmre, s. 279; Çabri, N. 760.

34 Dural/Öz, s. 101; Çabri, N. 759.

35 BK-Weimar, vor. Art. 494 ZGB, N. 6; Oğuzman, s. 133; Dural, s. 45; İmre, s. 278; Çabri, N. 758; İşgüzar/Demir/Yılmaz, s. 76; Kılıçoğlu, Ahmet M.: Miras Hukuku, Ankara, 2012, s. 154-155; Karş. Köprülü, Bülent: Miras Hukuku Dersleri, İstanbul, 1985, s. 131; Yarg. HGK., 14.5.2014, 8-1077/664 (Kazanc1): "Eldeki olayda "eşlerden birisinin diğerinden önce vefatı halinde, ortaklığa ait mallarla bilcümle maddi ve manevi haklarının tamamının, sağ kalan eşe ait olacağına" yönelik sözleşmedeki kabulleri bir olumlu miras sözleşmesi olarak ayaktadır ve eşler açısından geçerli/bağlayıcıdır.” Karş. Kocayusufpaşaoğlu, Miras Hukuku, s. 129. Öğretide bir görüş ise iki taraflı miras sözleşmelerine, gerek Türk hukukunda ortak vasiyetnameye cevaz verilmiyor olmas1 gerekse mirasçı zararına bu şekilde muhataralı sözleşmeler yapılmaması gerekçeleriyle karşı çıkmaktadır: Hatemi, §7 N. 56-57.

36 Kocayusufpaşaoğlu, Miras Hukuku, s. 129; Dural, s. 44; İmre, s. 277; Çabri, N. 757; İnan/Ertaş/Albaş, s. 255; Karş. Guinand, Jean/Stettler, Martin/Leuba, Audrey: Droit de successions, Zürih, 2005, N. 348-349, yazarlar ivazı bir ölüme bağlı tasarrufun oluşturabileceğini kabul etmektedir. Aynı yönde: SHK-Cotti, Art. 494 CC, N. 7; Piotet, s. 160; CR-Abbet, Intro. Art. 494-497 CC, N. 5. 
İki taraflı ivazsız miras sözleşmelerinde farklı bir değerlendirme yapmak gerekir. Bu sözleşmelerde herhangi bir taraf sağlararası borç altına girmese de her iki taraf açısından da yapılan kazandırma bir diğerinin varlık sebebini oluşturur ${ }^{38}$. Bu nedenle miras sözleşmesinin bağlayıcı içeriğini oluşturan karşılıklı ölüme bağlı tasarruflar arasında gerçek anlamda ${ }^{39}$ bir karş1lık ilişkisi bulunmasa ${ }^{40}$ da TBK m. $28^{\prime}$ 'in örnekseme yoluyla MK m. 5 gereği uygulanmasında bu açıdan engel yoktur ${ }^{41}$. Dolayısıyla ölüme bağlı tasarruflarla yapılan kazandırmalar arasında oransızlık denetiminin elverişliliği, her bir kazandırmanın niteliğine göre yapılmak gerekir.

İvazlı miras sözleşmelerinde ise ivaz olarak kararlaştırılan sağlararası kazandırma ile ölüme bağlı tasarruf arasında teknik anlamda bir karşılık

38 Tuor, Vorb, zum Erbvertrag, N. 11; Piotet, s. 160, yazar ivazlı miras sözleşmelerinin teknik olarak sinallagmatik olduğu fikrindedir. Aynı görüşte: CR-Abbet, Intro. Art. 494497 CC, N. 5; İki taraflı miras sözleşmesinde birbirinden bağımsız iki ayrı sözleşme olduğu, geçerliliklerinin birbirinden bağımsız olduğu, ancak taraf iradeleri uyarınca pek çok halde bu iki sözleşmenin geçerliliğinin birbirine bileşik sözleşme gibi bağlanmış olacağı: Dural, s. 46-47; Escher, Vor. Art. 494 ZGB, N. 13; BSK-Breitschmid, Vor. 494-497 ZGB, N. 14; Benzer şekilde: Antalya/Sağlam, N. 983; BK-Weimar, vor. Art. 494 ZGB, N. 6; Karş. SHK-Cotti, Art. 494 CC, N. 6, yazar iki taraflı miras sözleşmesinde karşılıklı ölüme bağlı tasarrufların geçerliliğinin birbirine bağlı olmayabileceğini de kabul etmektedir. Karş. CR-Abbet, Intro. Art. 494-497 CC, N. 6, yazar kural olarak bağlı̆̆ının kabul edilmesi gerektiğini belirtmektedir. Ayrıca, iki ayrı sözleșmenin bulunduğu hususunda: İmre, s. 278. Aksi yönde karşılık ilişkisi bulunmadığı için aşırı yararlanmanın gerçekleşemeyeceği görüşünde: Hatemi, Hüseyin: "Miras Sözleşmelerinde Gabin Söz Konusu Olabilir mi?", Prof. Dr. Necip Kocayusufpaşaoğlu için Armağan, Ankara, 2004, s. 192. İki taraflı miras sözleşmelerinin tek ve bir sözleşme oluşturduğu fikrinde: Piotet, s. 171.

39 Zira işlemle birlikte tarafların malvarlıklarına yönelmiş bir kazandırma yoktur. Her iki taraf açısından da yaptığı tasarruf, ölümle sonuç doğuracaktır. Escher, Vor. Art. 494 ZGB, N. 13; Miras sözleşmesiyle ölüme bağlı tasarrufta bulunan tarafın borçlanmadığı: Tuor, Art. 494 ZGB, N. 1.

40 Dural, s. 45; Kocayusufpaşaoğlu, Miras Hukuku, s. 244-245; Bıçakçı, s. 17; Antalya, Feragat, s. 94; BK-Weimar, vor. Art. 494 ZGB, N. 7; Kendine özgü borçlandırıc1 etkiden yoksun bağll1ık şeklinde: Serozan, Kazandırma, s. 102; Miras sözleşmesinde ölüme bağlı tasarrufta bulunan tarafın borçlanmadığı gerekçesiyle: Serozan/Engin, $\S 4$ N. 9e-10. İvazlı olumsuz miras sözleşmeleri bakımından ivaz ve müstakbel miras payı arasında karş1lık (sinallagma) ilişkisi olduğu görüşünde: Eren, Fikret/Yücer Aktürk, İpek: Türk Miras Hukuku, Ankara, 2019, s. 183.

41 Aksi yönde: Başoğlu, s. 407, yazar salt ivazlı miras sözleşmeleri açısından aşırı yararlanma hükmünün uygulanmasına olanak vermektedir. İvazlı miras sözleşmelerinde uygulanabileceği şeklinde: Arbek, Ömer: Miras Hukukunda Ölüme Bağlı İşlemlerde İrade Serbestisi Sınırları ve Müeyyidesi, Ankara, 2007, s. 74; Dural, s. 288-289; Serozan/ Engin, $\S 4$ N. 61; Atlı, s. 178. 
ilişkisi bulunmasa ${ }^{42}$ dahi, karşıllk benzeri bir ilişkinin ${ }^{43}$ bulunduğu için örnekseme yoluyla aşırı yararlanma hükmünün uygulanmasına bir engel olduğu ileri sürülemez ${ }^{44}$. Sağlararası ve ölüme bağlı kazandırma birbirlerinin varlık sebebini oluşturur. Nitekim yasa koyucu da bu hususu doğrudan doğruya benimseyerek MK m. 574 hükmünü sevk etmiştir. Bu hüküm ile ivazın ifa edilmemesi halinde miras sözleşmesine sona verilebilmesine, borçlu temerrüdü hükümlerine hüküm içi atıf yapılarak olanak tanınmıştır ${ }^{45}$.

\section{IVAZLI VEYA İKI TARAFLI MIRAS SÖZLEŞMELERI BAKIMINDAN DEĞERLENDİRME}

\section{A. Olumlu Miras Sözleşmelerinde}

\section{Genel Olarak}

İvazlı olumlu miras sözleşmelerinde, bir taraf sağlararası borç altına ${ }^{46}$ girerken karşı taraf, mirastan feragat beyanını kabul etmek dışında bağlayıcı bir ölüme bağ ${ }_{1}{ }^{47}$ tasarrufta bulunur. Böylece bir taraf sağlararası, diğer taraf ölüme bağlı kazandırma yapar. Ancak bu noktada, bir tarafın ölüme bağlı bir kazandırma da mı bulunduğu, yoksa vadenin ölüm olarak belirlendiği sağlararası bir işlem mi yapıldığı hususuna dikkat edilmelidir. Tarafların, tereke üzerinde bir işlem yapmayıp bir tarafın ölümüyle bu tarafa ait bir malvarlı̆g 1 unsurunun karşı tarafa intikal etmesini öngördükleri bir işlem yapmaları,

42 Ölüme bağlı tasarruf her zaman mortis causa yapıldığından, sağlararası kazandırmanın sebebini oluşturmaz ve bu itibarla iki tür kazandırma arasında gerçek anlamda karşılık ilişkisi bulunmaz: Dural, s. 50-51.

43 Dural, s. 51.

44 Velidedeoğlu, H. Veldet: Türk Medeni Hukuku, İstanbul, 1963, s. 528; Dural, s. 289; Turan, s 72-73; Bıçakçı, s. 109; Atlı, s. 178.

45 Dural, s. 288.

46 Öğretide bir görüş, olumlu miras sözleşmelerinde sadece ölünceye kadar bakma ediminin ivaz teşkil edebileceğini kabul etmektedir: Hatemi, $§ 7$ N. 50.

47 Miras sözleşmesinin bağlayıcı içeriğini, mirasçı atama, vasiyet bırakma, bu tasarruflara ilişkin ikameli tasarruflar, yüklemeler ve mirastan feragat beyanını kabul oluşturabilir. Bunun dışındaki ölüme bağlı tasarruflar vasiyetname hükümlerine tabi olur. Piotet, s. 160 ve 163; CR-Abbet, Intro. Art. 494-497 CC, N. 4. Mirasçılıktan çıkarma açısından açıklamalar ve farklı değerlendirmeler için: Yağcı, Kürşad: Cezai Mirasçılıktan Çıkarma, İstanbul, 2013, s. 408. Karş. Vasiyeti yerine getirme görevlisi atama ve görevliye ölüme bağlı kazandırma yapılan bir içerikle miras sözleşmesi kurulabileceği fikrinde: Akbıyık, Cem: Vasiyeti Yerine Getirme Görevlisi, İstanbul, 2012, s. 41 dn. 123. Ayrıca, vakıf kurma ölüme bağlı tasarrufunun miras sözleşmesinin bağlayıcı içeriğine dâhil olabileceği görüşünde karş. Uyan, Göktürk: "Miras Sözleşmesinde İki Taraflı Bağlayıcı Kayıtla Vakıf Kurulması”, IÜHFM C. 65 S. 2 (2007), s. 332 vd. 
miras sözleşmesiyle vasiyet bırakılmasını kararlaştırmalarına göre pek çok durumda daha muhtemeldir. Zira bir tarafa sağlararası işlem yoluyla kazandırma yapan kişinin bunun karşılı̆̆ını sağlararası bir kazandırma ile elde etmek istemesi çok daha yakın bir olasılıktır. Bu nedenle, öncelikle işlemin sağlararası veya ölüme bağlı tasarruf niteliğinin tespit edilmesi gereklidir ${ }^{48}$. Ancak belirtmek gerekir ki miras sözleşmeleri için öngörülen şekil koşulları, işlemin miras sözleşmesi sayılmama olasılı̆̆ını zayıflatacaktır. Zira bu durumda miras sözleşmesi için öngörülen şekle uyan tarafların iradelerinin ölüme bağlı tasarrufta bulunma yönünde olduğu çıkarımı daha güçlü bir şekilde yapılabilir.

Taraflar arasında miras sözleşmesi kurulduğu sonucuna varıldığında, karşılaştırma yapılması gereken kazandırmalar, bir yanda ivaz; diğer yanda ölüme bağlı tasarruf ile yapılan kazandırmadır. Şu kadar ki, sağlararası işlemle borç altına giren, aynı zamanda ölüme bağlı tasarrufta da bulunuyorsa sağlararası kazandırmayla birlikte bu tasarrufun da nazara alınması gerekir. İki taraflı olumlu miras sözleşmesinde ise her iki tarafın yaptığı ölüme bağlı tasarruf dikkate alınacaktır.

Miras sözleşmesi yapıldığ 1 anda karşıllık teşkil eden kazandırmalar arasındaki dengeyi değerlendirmek, edim muhatara içermiyorsa sağlararası kazandırma (ivaz) açısından herhangi bir güçlük oluşturmaz ${ }^{49}$. Bu konunun

Ölüme bağlı tasarruf niteliğinin tespiti hususunda: Serozan, Kazandırma, s. 15 vd.; Kocayusufpaşaoğlu, Miras Hukuku, s. 125-126; Oğuzman, s. 96-97; Çabri, N. 512 vd.; İnan/Ertaş/Albaş, s. 160; Öztan, Bilge: Miras Hukuku, Ankara, 2018, s. 165; Gönensay/Birsen, s. 39; Antalya/Sağlam, N. 371 ve 375; Guinand/Stettler/Leuba, N. 244-245; SHK-Cotti, Art. 494 CC, N.15 vd.; Piotet, s. 177; Arpacı, Özge: "Mahkeme Kararları Işı̆̆ında Ölüme Bağlı Tasarruf ile Sağlar Arası Hukuki İşlemlerin Ayrımında Geliştirilen Kriterler", Ankara Hacı Bayram Veli Üniversitesi Hukuk Fakültesi Dergisi C. 24 S. 1 (2020), s. 148 vd.; Druey, $\$ 8$ N. 34 vd.

$\mathrm{Bu}$ açıdan öğretide sağlararası edim borçlusunun aşırı yararlanmaya başvurabileceği ifade edilmiştir (Hatemi, Gabin, s. 192). Aşırı yararlanmaya başvurulabilmesi karşlık ilişkisi gerektirdiği için bu olanağın diğer tarafın da sahip olması gerekir. Bununla birlikte yazar bu olanağı sağlararası edim tahhüt edilmediği gerekçesiyle kabul etmemektedir. Ayrıca, aşırı yararlanma açısından edimler arası dengesizliğin nasıl takdir edilebileceğine de açıklama getirilmemiştir. Diğer yandan ölünceye kadar bakma sözleşmesinde bakım ediminin kapsamı karşı tarafın yaşam süresine bağlı olduğundan yine muhataralı bir edim söz konusu olacaktır. Tunçomağ, Kenan: Ölünceye Kadar Bakma Akdi, Ankara, 1959, s. 27 ancak karş. s. 80. Yazar burada, sözleşmenin muhataralı niteliği nedeniyle sözleşme kurulduğu an itibarıyla kimin aleyhine olacağının belirlenemeyeceğini ifade etmekle birlikte, pek çok halde hak düşürücü sürenin geçmesi nedeniyle sözleşmenin iptal edilemeyeceğini savunmaktadır. Fakat kanımızca bu gerekçenin, işlemin geçerliliğinin kurulduğu an itibarıyla değerlendirilmesi ilkesiyle bağdaşmadığ 1 ifade edilebilir. 
ayrıca incelenmesini zorunlu kılan, miras sözleşmesinin bağlayıcı içeriğine dâhil olan ölüme bağlı tasarrufla yapılan kazandırma açısından yapılacak değerlendirmedir.

Aşırı yararlanma nedeniyle iptale nesnel unsur açısından başvurulamadığı olasılıklarda, olumsuz miras sözleşmesine ilişkin kısımda değinileceği üzere, bir tarafın karşı tarafın zor durumda olmasından, düşüncesizlik veya deneyimsizliğinden yararlanma kastıyla aşırı menfaat elde etmek amacıyla miras sözleşmesini kurması, sözleşmenin kuruluş tarzı açısından ahlaka aykırılık sonucu ile işlemin hükümsüzlügü sonucunu doğurabilir. Culpa in contrahendo sorumluluğu dahi söz konusu olabilir. Ayrıca belirtmek gerekir ki aşırı yararlanmanın söz konusu olduğu pek çok durumda irade bozukluğu da bulunabilir ${ }^{50}$. Bu nedenle sözleşmenin kuruluş tarzı sebebiyle bir irade bozukluğunun koşulları da gerçekleşmişse, bu irade bozukluğuna özgü sonuçlara başvurulması olanağı saklıdır.

\section{Mirasçı Atama Tasarrufları}

Sağlararası kazandırma karşılığında, ölüme bağlı kazandırma olarak mirasçı atandığ 1 takdirde, aşırı yararlanma hükümlerinin uygulama alanı bulmas1 olanaksızdır. Çünkü mirasçı atanmasıyla, lehine ölüme bağlı kazandırmada bulunulan şahsa belirli bir değerin, tereke üzerinden de olsa, aktarılması taahhüdünde bulunulmamaktadır. Mirasın açılmasıyla birlikte, mirasçı atanan şahıs, tereke üzerinde öngörülen ölçüde külli halef olarak hak kazanmaktadır ${ }^{51}$. Başka bir deyişle, mirasçı atananının kazanımı tamamen tereke mevcuduna bağlı durumdadır ${ }^{52}$. Bu bağlamda mirasçının, miras

50 Kocayusufpaşaoğlu, $\S 39$ N. 2 ve 26.

51 Kocayusufpaşaoğlu, Miras Hukuku, s. 258; İmre, s. 186; Dural, Mustafa/Öz, Turgut: Türk Özel Hukuku Cilt IV Miras Hukuku, İstanbul, 2016, s. 142; İnan/Ertaş/Albaş, s. 221; Eren/Yücer Aktürk, s. 140; Köprülü, s. 169-170; Çabri, N. 576; Piotet, s. 82-83; Taşatan, Caner: "Türk Medeni Kanunu'na Göre Mirasçı Atama”, İNÜHFD 10(1)-2019, s. 41.

52 Kocayusufpaşaoğlu, Miras Hukuku, s. 251; Oğuzman, s. 132; İmre, s. 282; Taşatan, s. 42; BK-Weimar, Art. 494 ZGB, N. 17. Şu kadar ki mirasbırakanın, mirasçı atadı̆̆ 1 kişinin menfaatine kasten aykırı olarak sağlararası ivazsız kazandırmalar yaptığında, MK m. 656 b.4'ün örneksemeyle uygulanması mümkündür: Dural/Öz, s. 130; Kocayusufpaşaoğlu, Miras Hukuku, s. 248; Piotet, s. 165; Ayan, Serkan: "Olumlu Miras Sözleşmelerinin İçeriğine Aykırı Hukuki İşlemlere İtiraza Yönelik Medeni Kanun'un 527/II Hükmünün Anlamı", Terazi Hukuk Dergisi, S. 58 Y. 6 (Haziran 2011), s. 24; $\mathrm{Bu}$ hüküm kapsamına mirasçı atama halinde miras sözleşmesinde devredilmeyeceği kararlaştırılan malvarlığı unsurlarının da gireceği görüşünde: Gauthier, Jean: Le pacte successoral, Lozan, 1955, s. 44. Öğretide ayrıca, mirasçı atadığı kişiye karşı mirasbırakanın sağlararası bir işlemle ivazsız kazandırmada bulunmayacağını taahhüt 
açılmadan önce, teknik anlamda ne mirasçılık sıfatına ne de tereke mevcuduna dair bir beklenen hakkı dahi yoktur ${ }^{53}$. Miras açıldıktan sonra tereke

edebileceği, bu durumda MK m. 527/II hükmüne başvurulabileceği ileri sürülmektedir (Dural/Öz, s. 130; İmre, s. 284; Kocayusufpaşaoğlu, Miras Hukuku, s. 248; İnan/ Ertaş/Albaş, s. 257; Çabri, N. 776). Buna karşılık kanımızca, sağlararası bir taahhütle MK m. 527/II hükmünü uygulanabilir kılmak mümkün olmadığı gibi bu işlemin sağlararası işlem yapma özgürlüğüne getirdiği sınırlama itibarıyla geçerliliği MK m. 23/II karşısında tartışmalı olacaktır. MK m. 23/II'ye uygun olduğu ölçüde geçerlilik tanınması yönünde: BSK-Breitschmid, Art. 494 ZGB, N. 6; BK-Weimar, Art. 494 ZGB, N. 16; CR-Abbet, Art. 494 CC, N. 8; Ayan, s. 16, yazar bu taahhüde aykırılığın sonuçlarının borçlar hukukuna tabi olacağını haklı olarak kabul etmektedir: s. 17. Benzer yönde borçlar hukukuna tabi anlaşma da yapılabileceği şeklinde: Piotet, s. 165, yazar; ölüme bağlı tasarrufun içeriğine dâhil olarak da yapılmasını mümkün görmektedir. Tuor, Art. 494 ZGB, N. 20; Druey, $§ 10$ N. 39); CR-Abbet, Art. 494 CC, N. 8. Ayrıca karş. İnan/ Ertaş/Albaş, s. 257, yazarlar ayrı bir taahhüt olmadığı durumda dahi mirasbırakanın kasten malvarlı̆̆ını azaltması olasıllı̆ında atanmış mirasçıya karşı sorumlu olacağını kabul etmektedir. Hâlbuki atanmış mirasçıları, yasal mirasçılardan üstün tutmaya gerek yoktur: Kocayusufpaşaoğlu, Miras Hukuku, s. 251. Ayrıca, MK m. 565/b. 4'ün ivazlı tasarruflarda uygulanabileceği görüşü: Kocayusufpaşaoğlu, Miras Hukuku, s. 251; Bu durumda kazandırma yapılanın mirasbırakanın amacına katılması kaydıyla MK m. 527/ II'nin uygulanacağı fikrinde: Çabri, N. 784. Ayrıca karş. CHK-Hrubesch-Millauer, Art. 494 ZGB, N. 12a, Yazar hem vasiyet hem mirasçı atama açısından ivazlı miras sözleşmelerinin örtülü olarak bağışlama yapmamaya yönelik taahhüt içerdiğini, bu nedenle İMK m. 494/III (MK m. 527/II) hükmünün uygulama alanı bulması gerektiğini kabul etmektedir. Vasiyete ilişkin olarak miras sözleşmesinin bağlayıcı içeriğe sahip olduğundan hareketle aynı yönde: Piotet, s. 166.

53 Serozan, Kazandırma, s. 16; Dural/Öz, s. 51; Guinand/Stettler/Leuba, N. 347; Engin, B. İlkay: Yedek Mirasç1lık, İstanbul, 2003, s. 129; Serozan/Engin, §1 50, §4 N. 37-38 ve 131; Nomer, Haluk N.: Beklenen Haklar Üzerindeki Tasarrufların Hukuki Sonuçları, İstanbul, 2002, s. 130-131; Akkanat, s. 6; Küçükaydın, E. Aslı: "Mirasçı Atama", IÜHFM C. 75 S. 1 (2017), s. 440; İnce, Nurten: "Miras Bırakanın Güven Sorumluluğu (Culpa in Testando)", İNÜHFD C. 9 S. 1 (2018), s. 154; Ayan, s. 17; Tuor, Art. 494 ZGB, N. 10-11; Escher, Art. 494 ZGB, N. 2; Piotet, s. 75 ve 158; CR-Baddeley, Margareta: Art. 483 CC, N. 25; BK-Weimar, Art. 494 ZGB, N. 9. Ayrıntılı değerlendirme ve beklenen hakkın bağımsızlaşma gerçekleşmediği için söz konusu olmadığ görüşü için: Antalya/Sağlam, N. 136; Benzer yönde: Albaş, Hakan: "Mirastan Feragat Sözleşmesi ve Hükümlerine İlişkin Bazı Sorunlar", Dokuz Eylül Üniversitesi Hukuk Fakültesi Dergisi C. 9 (Özel Say1-2007), s. 537-538 ancak karş. 353; Lange, Knut Werner: Erbrecht, Münih, 2017, §44 N. 67. Ayrıca karş. Dural, s. 25; Yakupoğlu, s. 44, yazar beklenen hakkın söz konusu olmadığını ancak sınırlı olarak korunan bir beklentinin bulunduğunu, salt miras hakkına dair bir umuttan söz edilemeyeceğini kabul etmektedir. BSK-Breitschmid, Peter: Vor. Art. 494-497 ZGB, N. 4. Aksi yönde karş. Druey, §8 N. 12 vd.; CR-Abbet, Art. 494 CC, N. 2; Yıldırım, Mustafa Fadıl: "Beklenen (Açılmamış Bir Terekedeki) Miras Hakkının Devri Sözleşmesi (I), Yargıtay Dergisi C. 21 S. 1-2 (Ocak-Nisan 1995), s. 117; Özakman, H. Cumhur: Miras Payının Devrine İlişskin Sözleşmeler, İstanbul, 1984, s. 108; SHK-Cotti, Art. 494 CC, N. 65; 
mevcudu üzerindeki mirasçılık payı oranında tam hak (Vollrecht) iktisap eder. Başka bir deyişle, miras sözleşmesi mirasbırakanın işlem ehliyetini ve tasarruf yetkisini sinırlamaz (MK m. 527/II) ${ }^{54}$. Bu yönüyle mirasçı atanması halinde doğan hukuki durumu, muhataralı -sonucu talih ve tesadüfe bağlı (contrats aléatoires/aleatorische Verträge, Glücksverträge, Risikoverträge)bir sözleşmeye benzetmek mümkündür ${ }^{55}$. Muhataralı sözleşmelerde de edimlerden birinin kapsamını sözleşme kurulduğu an belirlemek mümkün olmadığından aşırı yararlanma hükümlerine dayanabilmek olanaklı değil$\operatorname{dir}^{56}$. Nitekim bu durumda sözleşme tarafları bu riski bilerek ve üstlenerek

BK-Weimar, Art. 494 ZGB, N. 8; Arpacı, s. 131; Bıçakçı, s. 16; Yarg. 14. HD., 28.11.2019, 2152/7969 (Kazancı) "Mirastan feragat sözleşmesinin hükümleri özellikle feragat eden mirasçı bakımından önemlidir. Çünkü, feragat sözleşmesi yapmakla feragat eden kimse, mirasa ilişkin beklenen (muntazar) bir haktan yoksun olur, mirasçı sıfatını kazanamaz. Bu husus Medeni Kanunumuzun 528/II'de «Feragat eden, mirasçılık sıfatını kaybeder» şeklinde ifade edilmiştir."

54 CR-Baddeley, Art. 483 CC, N. 26; Serozan/Engin, §4 N. 121; Çabri, N. 765; Dural, s. 144; SHK-Cotti, Art. 494 CC, N. 67; Piotet, s. 164; CR-Abbet, Art. 494 CC, N. 5; Akça, s. 207; Ölüme bağlı tasarrufun hükümlerini ancak mirasın açılmasıyla doğurduğu gerekçesiyle: Guinand/Stettler/Leuba, N. 351; Druey, §10 N. 35.

55 BSK-Breitschmid, Art. 494 ZGB, N. 5. Keza aynı benzetme umut satışı açısından da yapılabilir (Tandoğan, Haluk: Özel Borç İlişkileri, C. 1/I, İstanbul, 2010, s. 80; BKGiger, Art. 184 OR, N. 27). Muhataralı sözleşmeler için: Tandoğan, s. 6-7. Umut sat1şının da bir muhataralı işlem olduğu: Welser, Rudolf/Zöchling-Jud, Brigitta: Grundriss des bürgerlichen Rechts-Band II Schuldrecht Allgemeiner Teil Schuldrecht Besonderer Teil Erbrecht, Viyana, 2015, N. 813; KK-Karner, Ernst: ABGB Allgemeines Bürgerliches Gesetzbuch- KurzKommentar zum ABGB, Viyana, 2010, §1275-1276, N. 3. Açılmamış mirasa ilişkin pay devrinde de tarafların terekenin ve mirasçıllı sıfatının belirsizliği nedeniyle riziko üstlendikleri hakkında: Özakman, s. 107. Muhataralı sözleşmelerde tarafın bilincinde olduğu bir belirsizlik vardır: Reiner, Günter: Derivative Finanzinstrumente im Recht, Baden-Baden, 2002, s. 28.

56 Morin, N. 553-558; Haddat, Eloïse: Les notions de contrat d'assurance, Paris I Panthéon Sorbonne Üni. Doktora Tezi, Paris, 2017, N. 82; Okumuş, s. 82; Aslan, s. 101-103; Saymen, Nisbetsizlik, s. 158; Feyzioğlu, s. 251; Saymen/Elbir, s. 233; Feyzioğlu, s. 251. Olasılık hesaplarına dayanılabileceği hallerde uygulanabileceği nüansıyla: Kocayusufpaşaoğlu, §39 N. 11; Çakırca, s. 133-134 ve dn. 25; BKKramer, Art. 21 OR, N. 12. Yarg. 1. HD., 4.6.1982, 7801/7420 (Kazanc1). Aksi yönde uygulanılabileceği fikrinde: Sarı, s. 1030. Şunu belirtmek gerekir ki ölüme bağlı tasarrufta hem mirasın açılma anı hem de terekenin durumu, aktüerya hesabına uygun değildir. Bu görüş üstün tutulsa dahi miras sözleşmelerinde aşırı yararlanmanın uygulamasına zemin hazırlayamaz. Avusturya Medeni Kanunu $§ 1268$ hükmüyle muhataralı sözleşmeler bakımından aşırı yararlanmanın söz konusu olmayacağını açıkça düzenlemiştir. Ayrıca bkz. CR-Leuba, Art. 469 CC, N. 43, yazar genel olarak miras sözleşmelerinin kurulduğu an itibarıla mirasın açıldığ 1 andaki durumun öngörülemeyeceği gerekçesiyle aşırı yararlanmaya uygun olmadığını belirtmektedir. Karş. Akça, Neslihan: 
sözleşmeyi kurmuş durumdadır ${ }^{57}$. Bu itibarla, miras sözleşmesiyle mirasçı atanması olasılı̆̆ında, mirasçı ataması tasarrufu sözleşmeyi muhataralı hale getirir ve bu nedenle sözleşmeye aşırı yararlanma nedeniyle iptal edilebilirlik yaptırımının bütünüyle ve her iki taraf açısından uygulanmasına engel olur.

\section{Vasiyet Bırakma Tasarrufları}

Vasiyet şeklinde yapılmış bir ölüme bağlı tasarruf, miras sözleşmesinin içeriğinde bulunuyorsa daha farklı bir değerlendirme yapmak gerekir. MK m. 517/II hükmünde belirtildiği üzere vasiyet, bir kimseye terekedeki bir malın mülkiyetinin veya terekenin tamamı ya da bir kısmı üzerinde intifa hakkının kazandırılmasına yönelik olabileceği gibi; bir kimse lehine tereke değeri üzerinden bir edimin yerine getirilmesinin, bir iradın bağlanmasının veya bir kimsenin bir borçtan kurtarılmasının, mirasçılar veya belirli mal bırakılanlara yükletilmesi şeklinde yapılabilir. Bu durumda vasiyet, ölüme bağlı tasarrufta bulunanın, bir kişiye (vasiyet alacaklısı) alacak hakkı şeklinde ve cüz’i halefiyet aracıllı̆g ile sağladığı malvarlığı menfaati olarak tanımlanabilir ${ }^{58}$. Vasiyetin iki taraflı veya ivazlı miras sözleşmesi kapsamında yapılmasından engel yoktur ${ }^{59}$. Tanımdan görüldüğü üzere, mirasın açılmasıyla vasiyet alacaklısı lehine doğan bir alacak hakkı söz konusudur. Alacak

İvazlı Miras Sözleşmeleri, Ankara, 2020 (Gazi Üni. SBE. Doktora Tezi), s. 206, yazar bu hususu tespit etmekle birlikte, fazla menfaat edilmeye çalışıldığı hallerde aşırı yararlanmanın kurum olarak geniş yorumlanması gerektiğini savunmaktadır.

57 Okumuş, s. 82. Karş. Sigorta sözleşmesinde, olassılık hesabıyla aşırı yararlanmaya başvurulabileceği görüşü: Saymen/Elbir, s. 233; ZK-Kramer, Art. 21 OR, N. 12. Fikrimizce, aynı sebeple, tereke mevcudunu etkileyen malvarlığı artış ve azalışları miras sözleşmesinin uyarlanması için neden oluşturmaz. Burada tarafların sonuçlarını üstlendiği bir riskin gerçekleşmesi söz konusu olur. Olumsuz miras sözleşmesi açısından benzer yönde: SHK-Cotti, Art. 495 CC, N. 9 dn. 21; CHK-Hrubesch-Millauer, Art. 495 ZGB, N. 2.

58 Ŏguzman, s. 140; Dural/Öz, s. 143; İmre, s. 185; Eren/Yücer Aktürk, s. 140; Çabri, N. 585; BSK-Bruno Huwiler, Art. 484 ZGB, N. 1-2; SHK-Hubert-Froidevaux, Anouchka: Commentaire du droit des successions, Art. 484 CC, Bern, 2012, N. 1; BKWeimar, Art. 484 ZGB, N. 2; Piotet, s. 113; İnan/Ertaş/Albaş, s. 223, yazarlar borç ilişkisine konu olabilecek her ediminin vasiyet edilebileceğini ifade etmektedir. Aynı yönde: Serozan/Engin, §4 N. 138; Kılıçoğlu, Miras Hukuku, s. 142-143; SHKHubert-Froidevaux, Art. 484 CC, N. 2.

59 İvaz açısından: BSK-Huwiler, Art. 484 ZGB, N. 23; Dural/Öz, s 143-144; Oğuzman, s. 95 dn. 98a; İnan/Ertaş/Albaş, s. 223; Gönensay/Birsen, s. 132; Antalya/Sağlam, N. 756; Çabri, N. 764; SHK-Hubert-Froidevaux, Art. 484 CC, N. 1. Karş. Kocayusufpaşaoğlu, Miras Hukuku, s. 259, Yazar vasiyetin ivazsız bir kazandırma olduğunu belirtmekle yetinmektedir. Aynı şekilde: CHK-Hrubesch-Millauer, Art. 484 ZGB, N. 3; Escher, Art. 484 ZGB, N. 4; Tuor, Art. 484 ZGB, N. 6. 
hakkının konusunu oluşturan edim belirli veya belirlenebilirdir. Bu nedenle ilk aşamada kazandırmalar arasındaki oran açısından değerlendirmeye elverişli olduğu düşünülebilir. Ancak, MK m. 527/II hükmünde açıça belirtildiği üzere, ölüme bağlı tasarrufta bulunan, malvarlığ işlem yapma imkânını yitirmemiş ${ }^{60}$, sadece bağışlamalara karşı tenkis olanağ ${ }_{1}^{61}$ öngörülmüştür. Bunun dışında sağlararası ivazlı işlem sonucunda vasiyet konusu malvarlığından çıkarsa, MK m. 517/III gereği vasiyet düşmüş olur $^{62}$. Görüldüğü üzere, miras sözleşmesiyle vasiyette bulunulduğu takdirde, karş1 taraf ölüme bağlı tasarrufta bulunan tarafın sağlararası işlemde bulunma riskini üstlenmektedir. Farklı bir deyişle vasiyette bulunulması da mirasç1 atama gibi, muhatara içermektedir. Bu duruma, tedarik ${ }^{63} /$ çeşit $^{64}$

60 Çabri, N. 765; BK-Weimar, Art. 494 ZGB, N. 19; Karş. İmre, s. 285, yazar miras sözleşmesiyle vasiyet edenin, vasiyet konusunu ivazsız olarak devretmekten MK m. 2 uyarınca kaçınması gerektiğini belirtmekte birlikte bu durumda uygulanacak yaptırımdan söz etmemektedir.

Hükümde itiraz terimi kullanılmış olsa da, örnekseme ile tenkis davası hükümlerinin uygulanacağı kabul edilmektedir: Kocayusufpaşaoğlu, Miras Hukuku, s. 249-250; Oğuzman, s. 131; Dural/Öz, s. 131; İnan/Ertaş/Albaş, s. 257; Serozan/Engin, §4 N. 117; Antalya/Sağlam, N. 652; Çabri, N. 780; Ayan, s. 28; Guinand/Stettler/Leuba, N. 357; CR-Abbet, Art. 494 CC, N. 15. Karş. Tuor, Art. 494 ZGB, N. 19-20. Oğuzman, s. 131; Serozan/Engin, §4 N. 139; Hatemi, §8 N. 11; Çabri, N. 785.

Tedarik vasiyetinde, vasiyet borçlusu vasiyet konusunu tereke dışında olduğu için temin etmekle yükümlü olur: Eren/Yücer Aktürk, s. 147; Çabri, N. 611; CR-Baddeley, Art. 484 CC, N. 69; BK-Weimar, Art. 484 ZGB, N. 44; CHK-Hrubesch-Millauer, Art. 484 ZGB, N. 6; SHK-Hubert-Froidevaux, Art. 484, N. 24 ve 33; Druey,§11 N. 15 Piotet, s. 118. Bu hususiyet ölüme bağlı tasarrufta öngörülmelidir: Oğuzman, s. 141; Gönensay/Birsen, s. 134; Gürsoy, Kemal Tahir: Türk Medeni Kanunu Hükümlerine Göre Mal Vasiyeti, Ankara, 1955, s. 158; Tuor, Art. 484 ZGB, N. 25; Escher, Art. 484 ZGB, N. 19; BSK-Huwiler, Art. 484 ZGB, N. 80.

Çeşit vasiyetinde, terekede bulunması veya bulunması şart olmadan, vasiyet alacaklısına konusu çeşit borcu teşkil eden bir alacak kazandırılır: Oğuzman, s. 141; Çabri, N. 603; Gürsoy, s. 153; Gauthier, s. 51; CHK-Hrubesch-Millauer, Art. 484 ZGB, N. 5; CRBaddeley, Art. 484 CC, N. 32; SHK-Hubert-Froidevaux, Art. 484, N. 33 . Vasiyet borçlusu, vasiyet borcunu tereke dişında olsa dahi temin etmekle MK m. 519 hükmü sınırları içinde yükümlüdür: Ozanemre Yayla, H. Tolunay: "Ön Vasiyet (Mirasçı Lehine Vasiyet) Kavramı, Ön Vasiyetin Unsurları ve Özellikleri," Ankara Barosu Dergisi, 2017/2, s. 121; Dural/Öz, s. 146. Tedarik vasiyetinden farklı olarak, özellik çeşit borcunun niteliğinden kaynaklandığından, tereke dışından teminin ölüme bağlı tasarrufta özellikle kararlaştırılmış olması gerekmez. İrat vasiyeti dahi çeşit vasiyetinin özel bir görünümüdür (Genel olarak para vasiyetinde: CHK-Hrubesch-Millauer, Art. 484 ZGB, N. 5; BSK-Huwiler, Art. 484 ZGB, N. 62; Gürsoy, s. 153). Çeşit vasiyetinin terekede çıkmaması halinde tedarik vasiyetine dönüşeceği şeklinde: Eren/Yücer Aktürk, s. 145. 
vasiyeti istisna teşkil eder ${ }^{65}$. MK m. 517/III'teki karinenin aksi miras sözleşmesinde öngörülmüşse, miras açıldığında vasiyet konusunun terekede bulunmamas1, vasiyet borcunu düşürmez ${ }^{66}$. Bu ihtimalde, vasiyet borcu, muhatara içermediğinden ve vasiyet edilen edimin değeri belirlenebilir nitelikte olduğundan, aşırı yararlanma açısından değerlendirme yapmaya elverişli olarak kabul edilmek gerekir ${ }^{67}$.

Belirtilen türdeki vasiyet bırakma tasarrufları ile onlara karşılık oluşturan muhatarasız sağlararası kazandırma (ivazlı miras sözleşmesi) veya yine aynı türdeki vasiyet bırakma tasarrufları (iki taraflı miras sözleşmesi) arasında açık bir oransızlık bulunuyorsa ve aşırı yararlanmanın öznel unsurları da gerçekleşmişse, miras sözleşmesi aşırı yararlanma ile malul olur. $\mathrm{Bu}$ durumda, oransızlık aleyhine gerçekleşmiş taraf, sağlararası kazandırmada bulunmuşsa TBK m. 28 hükmüne dayanarak işlemi iptal edebilir ${ }^{68}$. Buna karşılık ölüme bağlı tasarrufta bulunan taraf aşırı yararlanmaya maruz kalmışsa TBK m. 28, MK m. 5 hükmü aracılığı ile uygulanır. Miras sözleşmesi, ölüme bağlı tasarrufta bulunan tarafından düşüncesizlik veya deneyimsizliğini öğrendiği; zor durumda kalmada ise, bu durumun ortadan kalktığı tarihten başlayarak bir yıl ve her hâlde sözleşmenin kurulduğu tarihten başlayarak beş yıllık hak düşürücü süre içinde iptal edilebilirr ${ }^{69}$. Bu kabul, MK m. 504 hükmüyle de uyumludur. Hak düşürücü süre dolmadan ve iptal hakkından feragat etmeden ölüme bağlı tasarrufta bulunan ölürse, MK m. 557 ve

65 Serozan/Engin, $\S 4$ N. 139. Ayrıca, tarafların miras sözleşmesinde açıkça veya örtülü olarak kaim değerin vasiyet konusu olmasını kararlaştırmaları da mümkündür. $\mathrm{Bu}$ olasılıkta yapılacak değerlendirme açısından belirleyici olan miras sözleşmesi kurulduğu anda kaim değerin belirli olup olmadığıdır.

66 Dural/Öz, s. 147; Kocayusufpaşaoğlu, Miras Hukuku, s. 263 ve 266; İmre, s. 285; İvazlı miras sözleşmelerinde karine olarak vasiyet borcunun devam edeceğinin kararlaştırılmış sayılacağı: Tuor, Art. 494 ZGB, N. 25; Escher, Art. 494 ZGB, N. 12; CRAbbet, Art. 494 CC, N. 7; Benzer yönde: Piotet, s. 165; İvazlı ve ivazsız miras sözleşmesinde, vasiyet borcunun, vasiyet konusunun değerini ödeme borcuna dönüşeceği şeklinde: Ayan, s. 30.

İvaz karşıllğı vasiyette bulunulmasında kazandırmalar arasında nesnel bir denge bulunmasının gerekmediği öğretide belirtilmekte (BSK-Huwiler, Art. 484 ZGB, N. 27) ise de bu durum, diğer bütün koşulların gerçekleştiği takdirde aşırı yararlanmanın doğmasına engel olmamalıdır.

Sağlararası işlem yapan açısından genel hükümlerin uygulandığı: SHK-Cotti, Art. 494 CC, N. 8; Eren, İptal, s. 91; Turan, s. 97; CR-Leuba, Art. 469 CC, N. 7; Dural, s. 271; Atll, s. 113.

69 Dural, s. 289; Atlı, s. 179. Bu durumda, miras sözleşmesi karşı tarafa yöneltilmesi gerekli ve şekle bağlı olmayan iptal beyanı ile hükümsüzleşecektir: Kocayusufpaşaoğlu, Miras Hukuku, s. 333; Oğuzman, s. 106; Çabri, N. 312 
m. 559 örneksemeyle uygulanır. Mirasçılar sözleşmenin iptalini dava edebilir $^{70}$. Sadece sağlararası kazandırmaya müdahale yoluyla kazandırmalar arasındaki oransızlığı gidermek mümkünse, iptal yerine oransızlı̆̆ın giderilmesi olanağı da bulunabilir ${ }^{71}$. Buna karşılık, oransızlığın giderilmesi maksadıyla ölüme bağlı tasarruflara ilişkin bir müdahale yapılmasına olanak tanınmaması, münhasıran şahsa bağlı nitelik gösteren ölüme bağlı tasarrufta bulunma özgürlüğüne müdahale teşkil edeceği için kanımızca daha yerinde olacaktır. Aşırı yararlanmaya maruz kalan ölüme bağlı tasarrufta bulunanın mirasçıları, MK m. 557-559 hükümlerine örneksemeyle iptal davası açabileceklerinden ve bu davada öngörülen tek yaptırım işlemin iptali olduğundan, oransızlığın giderilmesi imkânı hiçbir şekilde söz konusu olmayacaktır.

\section{B. Olumsuz Miras Sözleşmelerinde}

Olumsuz miras sözleşmesinde, mirasbırakan karşı tarafın kendisinin mirasçısı olma sıfatından ${ }^{72}$ feragat ettiğine ilişkin iradesini kabul etmek suretiyle ölüme bağlı tasarrufta bulunur ${ }^{73}$. Mirasbırakan bunun karşılığında

70 Dural, s. 289; Atlı, s. 179.

71 Karş. Oransızlığın giderilmesi olanağının genel olarak her olasılıkta bulunduğu görüşünde: Çabri, N. 1295.

$72 \mathrm{Bu}$ sözleşmenin geçerliliği için sözleşme kurulduğu anda feragat edenin muhtemel mirasçı sıfatına sahip olması gerektiği yönünde: Yarg. 1. HD., 20.11.2018, 15019/14670 (Kazanc1) "Somut olaya gelince, her ne kadar davac1 27.02.2007 tarih ve ... yevmiye numaralı ... 24. Noterliği'nde düzenlenen mirastan feragat sözleşmesi ile miras hakkından feragat etmiş ise de feragat tarihi itibarı ile mirasçı sıfatının olmadığı sabittir. O halde, noterde düzenlenen feragat sözleşmesi TMK m. 528 anlamında bir feragat sözleşmesi olmadığı gibi doğmamış haktan feragat edilemeyeceği, bu beyana hukuki sonuç bağlanamayacağı açıktır. Ne var ki, muris muvazaası iddiası yönünden hükme yeterli bir araştırma yapılmamıştır.". Kanımızca olumsuz miras sözleşmesinin kurulduğu anda feragat beyanında bulunan tarafın olası mirasçısı sıfatı taşıması bir geçerlilik koşulu değildir. Bu husus sözleşmenin hüküm ifade etmesi için kanuni şart teşkil eder. Miras açıldığında feragat eden, feragat gerçekleşmemiş olsaydı mirasçı sıfatını kazanacak idiyse, sözleşme hükümlerini doğurur. Karara konu olan vakıalara benzer hallerde işlem geçerliliğini, irade bozuklukları ve ahlaka aykırılık açısından değerlendirmek daha yerinde olacaktır.

73 SHK-Cotti, Art. 495 CC, N. 1; BK-Weimar, Art. 495 ZGB, N. 3; İmre, s. 300; Eren/ Yücer Aktürk, s. 180; Oğuzman, s. 165, yazar mirasbırakanın durumunu daha iyi ifade etmek için ölüme bağlı tasarrufu "mirastan feragati sağlama" olarak ifade etmektedir. Karşı taraf sağlararası bir işlem olarak iradesini beyan etmekle yetinmektedir. Beklenen haktan dahi bir feragat söz konusu değildir. Karş. Dural/Öz, s. 195. Bu durumda iki taraflı bir mirasçılıktan çıkarma olduğu gerekçesiyle: Piotet, s. 158; Olumsuz miras sözleşmesinin öncelenmiş mirasçılıktan çıkarma sayılmayacağı görüşünde: CHKHrubesch-Millauer, Art. 495 ZGB, N. 1. Doğmamış haktan feragat edildiği gerekçesiyle kavramsal olarak mirastan feragatin hukuk mantığına uygun olmadığı görüşünde: 
feragat edene sağlararası bir kazandırmada bulunma borcu altına girerse, ivazlı miras sözleşmesi kurulur ${ }^{74}$. Mirasbırakanın ayrıca başka bir bağlayıcı ölüme bağlı tasarrufta bulunması da mümkündür ${ }^{75}$. Mirastan feragat eden, sadece feragat iradesini karşı tarafa açıklamaktadır. Bunun dışında sağlararası veya ölüme bağlı herhangi bir kazandırmada kural olarak bulunmamaktadır. Bununla birlikte, mirastan feragat iradesini açıklayan, tereke üzerindeki olası hakkının doğmasına engel olduğundan, feragat edilen olası miras hakkı ile mirasbırakanın sağlararası veya ölüme bağlı kazandırması arasında karşılık ilişkisi benzeri bir bağın bulunacağı ifade edilebilir ${ }^{76}$. Ayrıca, sözleşmenin bağlayıcı içeriğini oluşturan tarafların yaptığı başka sağlararası veya ölüme bağlı kazandırmalar varsa onlar da dikkate alınmalidır.

Kural olarak sağlararası ivaz ve çeşit/tedarik vasiyeti niteliğindeki ölüme bağlı tasarruf aşırı yararlanma bakımından elverişli kazandırma oluşturduğundan, bu olasılıkta aşırı yararlanmada kazandırmalar arasındaki oran açısından değerlendirilmesi gereken, olası miras hakkından feragatle vazgeçilen olası miras hakkının değerlendirme için elverişli olup olmamasıdır ${ }^{77}$. Zira ifade edildiği üzere, kazandırmalar arasındaki oransızlık açısından değerlendirme yapabilmek için her iki kazandırmanın da muhataralı olmaması gerekir.

Mirastan feragat halinde de mirastan feragatte bulunan, kendisi bak1mından muhataralı bir işlemde bulunmaktadır ${ }^{78}$. Zira bu olasılıkta vazgeçilen

Berki, Şakir: "Türk Medeni Kanununda Mirastan Feragat", Prof. Dr. Mahmut Koloğlu'ya Armağan, Ankara, 1975, s. 390.

74 Kocayusufpaşaoğlu, Miras Hukuku, s. 301; İnan/Ertaş/Albaş, s. 261. Karş. İvazın, ölüme bağlı kazandırma da teşkil edebileceği görüşü: SHK-Cotti, Art. 495 CC, N. 8; İFM, 25.5.2000, 5C.91/2000 (Swisslex).

75 İmre, s. 300-301; CR-Abbet, Art. 495 CC, N. 4; Piotet, s. 160; BSK-Breitschmid, Art. 495 ZGB, N. 6. Aksi yönde: BK-Weimar, Art. 495 ZGB, N. 15.

76 SHK-Cotti, Art. 495 CC, N. 7; BSK-Breitschmid, Art. 495 ZGB, N. 6. Öğretide ivazlı olumsuz miras sözleşmelerinde aşırı yararlanma nedeniyle hükümsüzlüğün doğmasına olanak tanıyan görüşün (Hatemi, Gabin, s. 192-193) bu hususu kabul ettiği sonucuna varilabilir.

77 Karş. CHK-Hrubesch-Millauer, Art. 495 ZGB, N. 2, yazar olumsuz miras sözleşmesinde miras açılana dek sürecek nesnel bir dengenin bulunmasının gerekmediğini, taraf iradeleri doğrultusunda öznel bir dengenin varlığının yeteceğini belirtmektedir.

78 CHK-Hrubesch-Millauer, Art. 495 ZGB, N. 2; BSK-Breitschmid, Art. 495 ZGB, N. 6 CR-Abbet, Art. 495 CC, N. 6, bununla birlikte yazar aşırı yararlanmanın uygulanabileceğini ileri sürmektedir. Karş. Berki, s. 402, yazar mirasın açıldığı andaki tereke durumuna göre ivazın gözden geçirilmesine ilişkin bir hükmün sözleşmeye eklenebileceğini kabul etmektedir. 
miras payının içeriği belirsizdir. Mirasçı atamada söz konusu olduğu gibi, burada da karşılık teşkil eden sağlararası veya ölüme bağlı kazandırma mukabilinde vazgeçilen olası miras payını sözleşmenin kurulduğu an itibarıyla değerlendirmek mümkün değildir ${ }^{79}$. Bu bağlamda miras payı üzerindeki olası hak, yukarıda değinildiği üzere beklenen hak teşkil etmez; salt beklentiden ibarettir. Bu beklentinin içeriğindeki belirsizlik, aşırı yararlanmada kazandırmalar arasındaki oran açısından değerlendirme yapılmasını olanaksız kılmaktadır ${ }^{80}$. Başka bir deyişle muhatara açısından mirasçı atanma ve mirastan feragat eşdeğerdir.

Genel olarak miras sözleşmelerinde aşırı yararlanma nedeniyle işlemin hükümsüzlüğüne başvuru gereksinimiyle, özellikle ivazlı olumsuz miras sözleşmeleri kapsamında karşılaşılır. Örnek olarak acil para ihtiyacı içinde bulunan çocuğuna mirasından feragat etmesi kaydıyla yardımda bulunmayı öneren anne verilebilir. Bu durumda annenin taahhüt ettiği ivaz ile çocuğun feragat ettiği olası miras hakkı beklentisi ${ }^{81}$ arasında görünüşte bir oransızlığın bulunması aşırı yararlanma nedeniyle iptal hakkının doğması gerektiği izlenimini haklı olarak doğurmaktadır. Ancak miras payı beklentisinin içerik olarak belirsizliği, aşırı yararlanma hükümlerinin uygulanmasını olanaklı k1lmaz.

Örneğe benzeyen hallerde aşırı yararlanma nedeniyle işlemin hükümden düşürülmesi olanağının tanınmıyor olması, bu durumlara cevaz verildiği şeklinde anlaşılmamalıdır. Bu olasılıkta, sözleşmenin kurulmasında ahlaka aykırılığın bulunduğu sonucuna varılmalı ve hukuki işlem ahlaka aykırılık nedeniyle hükümsüz sayılmalıdır. Zira sözleşme kurulurken bir taraf o olayda bulunduğu üstün konumundan istifade etmek suretiyle karşı tarafa açıkça onun menfaatlerine ölçüsüz derecede aykırı hükümler kabul ettirerek aşırı bir menfaat elde etmişse ahlaka aykırılık gerçekleşir ${ }^{82}$. Bu itibarla, aşırı

79 Yarg. 14. HD., 10.5.2016, 404/5691 (Kazanc1): "Mirastan feragat sözleşmesi miras bırakan ile gelecekteki muhtemel mirasçısı arasında düzenlenen, ileride doğacak miras hakkına dair beklentiden karşılık alınarak veya bir karşılık alınmadan kısmen veya tamamen vazgeçmeye dair iki taraflı bir sözleşmedir. Mirastan feragat sözleşmesinin konusunu murisin halen hayatta bulunması sebebiyle miras geçmediğinden miras hakk1 değil buna dair beklenti oluşturmaktadır."

Kazandırmalar arası dengenin sözleşmenin niteliği gereği belirsiz ve muhataralı olduğu: BSK-Breitschmid, Art. 495 ZGB, N. 6.

81 Burada nazara alınabilecek miras payının saklı pay olması gerektiği gözden kaçırılmamalıdır.

82 Kocayusufpaşaoğlu, $\S 42$ N. 47; Tekinay/Akman/Burcuoğlu/Altop, s. 401; Serozan, Dengesizlik, s. 1018-1019; Antalya, Borçlar Hukuku, s. 384; Huguenin, N. 413; SHKCotti, Art. 494 CC, N. 21; Kurşun, s. 192; Ayrıca haksız etkileme sonucunda elde 
yararlanma kurumunun sinırlarını zorlamak yerine söz konusu hallerde ahlaka aykırılık nedeniyle hükümsüzlük sonucunun doğduğunu kabul etmek daha doğrudur. Esas itibarıyla miras sözleşmesinin kuruluşundaki ahlaka aykırılık sebebiyle hükümsüzlük, salt olumsuz miras sözleşmelerine özgü bir olasılık değildir. Aynı olasılık olumlu miras sözleşmelerinde de mevcuttur.

\section{CULPA IN CONTRAHENDO SORUMLULUĞUNA BAŞVURMA OLANAĞI}

Aşırı yararlanma, sömürüde bulunan açısından taraflar arasında işlemsel temasın başlamasıyla MK m. 2 uyarınca doğan dürüst davranma ve zarar vermemeye yönelik koruma yükümlülüğünün ihlali anlamına gelir ${ }^{83} . \mathrm{Bu}$ çerçevede irade bozukluklarında söz konusu olduğu gibi, aşırı yararlanma halinde de kanunda açık bir hüküm bulunmasa dahi culpa in contrahendo sorumluluğu doğar. Miras sözleşmeleri açısından, teknik olarak karşıllıklı kazandırmalar arasında oransızlık değerlendirmesinin yapılamadığı hallerde bir tarafın karşı tarafin zor durumunu, düşüncesizliğini veya deneyimsizliğini sömürerek ölçüsüz menfaat sağlamasının yukarıda belirtilen koruma yükümlülüğ̈̈nün ihlalini teşkil edeceği sonucuna ulaşmak gerekir ${ }^{84} . \mathrm{Bu}$ durumda, karşı taraftan ölçüsüz menfaat elde etmek isteyen taraf culpa in

edilen büyük yararlanma halinde ahlaka aykırılığın gerçekleşebileceği: İFM, 9.4.2014, 4A_3/2014 (Swisslex); Haksız etkileme, ölüme bağlı tasarrufta bulunanın ayırt etme gücünü etkileyebilecek bir olgu da kabul edilmektedir: CR-Leuba, Art. 467 CC, N. 1516 ve 28; İFM, 5C.91/2000 (Swisslex), Federal Mahkeme bu kararında feragat eden açısından MK m. 23 hükmüne aykırılık söz konusu olduğunda miras sözleşmesinin hükümsüz olabileceğini kabul etmiştir. Ayrıca bkz. Serozan, Dengesizlik, s. 1019-1021. Aşırı yararlanma halinde de, yanılma ve aldatmada (hile) söz konusu olduğu gibi, culpa in contrahendo kökenli giderim isteminde bulunabileceği: Kocayusufpaşaoğlu, $\S 39 \mathrm{~N}$. 31; Von Tuhr/Peter, §40 II, s. 347; OFK-Dasser, Art. 21 OR, N. 10; CHK-Kut, Art. 21 OR, N. 23; BK-Kramer, Art. 21 OR, N. 61; Gauch/Schluep/Schmid, N. 748; Acabey, s. 113; Ergüne, M. Serkan: Olumsuz Zarar, İstanbul, 2008, s. 246; Tiftik, s. 414-415. Karş. Aşırı yararlanmanın haksız fiil oluşturacağı şeklinde: Birsen, s. 87-88; Ayrıca karş. Saymen/Elbir, s. 244. Kanımızca aşırı yararlanmanın, mutlak hak veya özel koruma normu ihlali sonucunda haksız fiil sorumluluğuna yol açacak şekilde hukuka aykırılığa sebebiyet vermesi söz konusu olamaz. Farklı yönde: Kuonen, Nicolas: La responsabilité précontractuelle, Zürih, 2007, N. 1820. Yazar, aşırı yararlanmanın gerçekleştiği her durumun sözleşme öncesi karşı tarafi koruma borcunun ihlal edildiği anlamına gelmeyeceği, sözleşmenin kuruluş aşamasında karşı tarafın ekonomik çıkarların gözetme yükümlüğünün bulunmadığı, culpa in contrahendo sorumluluğuna gi-dilebilmesi için bilgilendirme borcu gibi gerçek bir sözleşme öncesi yükümlülügünün ihlalinin gerektiği görüşündedir.

84 Aynı sorumluluk, miras sözleşmesinin ahlaka aykırılık nedeniyle malul olduğu durumlarda da ortaya çıkabilir. 
contrahendo sorumluluğu çerçevesinde yol açtığı olumsuz zararı gidermekle sorumlu olur ${ }^{85}$. Bu kapsamda talebin hukuki sebebi aşırı yararlanma veya ölüme bağlı tasarrufun kendisi değil mirasbırakanın veya karşı tarafin culpa in contrahendo sorumluluğu olmaktadır. Bu itibarla culpa in contrahendo sorumluluğunun miras hukukunda uygulanması, mirasçı veya vasiyet alacaklısının mirasın açılmasından önce beklenen hakkının bulunmadığı ilkesiyle çelişmez. Sözleşme kurmaya yönelik müzakere sürecinin başlamasıyla doğan koruma yükümlülüklerinin ihlali sonucunda bir tarafın culpa in contrahendo' dan sorumlu tutulması ile bu durum arasinda herhangi bir farklılık söz konusu değildir. Sağlararası kazandırmada bulunan taraf, mirasbırakanın zor durumunu, deneyimsizliğini veya düşüncesizliğini sömürü ile istismar ederek sözleşme öncesi koruma yükümlülüğünü ihlal ediyorsa, bunun olağan bir culpa in contrahendo sorumluluğundan fark1 yoktur. Aynı durum, mirasbırakanın koruma yükümlülüğünü ihlal ettiği senaryoda da geçerlidir.

Hatta belirtmek gerekir ki öğretide de yasal veya iradi mirasçılarının miras beklentilerinin beklenen hak teşkil etmemesine karşın, sağ kalan tarafın bu beklentisinin gerçekleşmemesinden ötürü mirasbırakanın sorumluluguna culpa in contrahendo sorumluluğunun yansıması çerçevesinde gidilebilmesi kabul görmeye başlamıştır (culpa in testando) ${ }^{86}$. Buna göre, mirasbırakan, özel bir bağlantıya ${ }^{87}$ sahip olduğu karşı tarafa ona vasiyette bulunacağı veya onu mirasçı atayacağı hususunda haklı bir güven ${ }^{88}$ verdikten sonra bu ölüme bağlı tasarrufta bulunmaz veya ölüme bağlı tasarrufu sonradan hükümden düşürürse, güveni boşa çıkan taraf, mirasbırakanın sağlığında

85 Kural olarak, olumsuz zararın giderilmesine yönelik bir talep hakk1 söz konusudur (Hirschlehner, Anna: "Culpa in testando - Vertrauenshaftung des Erblassers", Aktuelle Juristische Praxis 2017, s. 1185; BK-Kramer, Art. 21 OR, N. 61). Bununla birlikte karş1 tarafa zarar vermeme borcunun (koruma yükümlülüğü) ihlali de söz konusu olduğunda, bundan doğan zararın da giderilmesi talep edilebilir: Demirsatan, Barış: Türk Borçlar Kanunu Çerçevesinde Sözleşmenin Haksız Olarak Sona Erdirilmesi, İstanbul, 2019, s. 280 dn. 189. Koruma yükümlülüğü kapsamında olan bütünlük menfaati, olumlu veya olumsuz menfaatten farklıdır. Ancak olumlu veya olumsuz zararın tazmini talep edilirken onlarla birlikte ve ayrı olarak talep edilebilir.

Serozan, Rona: "Wohin steuert das Erbrecht?", successio 2014, s. 10; İnce, s. 170 vd.; Atlan, Hülya: "Miras Sözü Vermeden Doğan Kusurlu Sorumluluk: Culpa In Testando Sorumluluğu", MÜHF-HAD C. 23 S. 2, s. 273; Hirschlehner, s. 1183-1184, yazar culpa in contrahendo'nun culpa in testando için bir hukuki model olabileceğini belirtmektedir. 
uyandırdığı ve sonradan ihlal ettiğgi güven ilişkisinden doğan zararın giderilmesini talep edebilmelidir. Ancak çalışma, konusu açısından culpa in testando'nun kapsamı dışında kalmaktadır. Zira burada tarafların culpa in contrahendo sorumluluğunu doğuran, haklı miras umudunun gerçekleşmemesi değil, sözleşmenin kuruluş safhasındaki koruma yükümlülüğünün ihlalidir.

\section{SONUÇ}

Miras sözleşmelerinde TBK m. 28 hükmüne başvurulabilmesi MK m. 5 uyarınca kuramsal olarak mümkündür. Bununla birlikte miras sözleşmelerinde aşırı yararlanma nedeniyle hükümsüzlüğün unsurlarının gerçekleşip gerçekleşemeyeceği ayrı bir değerlendirme yapılmasını gerektirmektedir. Öznel unsurların gerçekleşmesine engel olacak bir hukuki durum söz konusu olmamakla birlikte, karşılıklı edimlerin varlığı ve bu edimler arasındaki açık oransızlık şeklinde ifade edilebilecek nesnel unsurun varlı̆̆ açısından götürü bir belirleme yapmak olanaksızdır.

İvazlı miras sözleşmelerinde ve iki taraflı miras sözleşmelerinde kazandırmalar arasında teknik olarak karşılık ilişkisi bulunmasa da kazandırmalar birbirlerinin varlık amaçlarını teşkil ettiğinden TBK m. 28'in MK m. 5 uyarınca örneksemeyle uygulanması için gerekli karşılıklılığı sağlar.

Ölüme bağlı tasarruf olarak mirasçı atama ve mirastan feragat beyanını kabulde, kazanılan veya vazgeçilen olası miras hakkının içeriği belirsiz olduğundan, söz konusu tasarrufları muhataralı işlem olarak kabul etmek gerekir. İçerik belirsizliği nedeniyle, oransızlık bakımından değerlendirme yapılması mümkün değildir. Vasiyette de vasiyet konusu üzerinde ölüme bağlı tasarrufta bulunanın sağlararası tasarrufta bulunma özgürlüğü devam ettiğinden; miras sözleşmesi kapsamında vasiyet şeklinde yapılan ölüme bağlı tasarruf da muhataralı işlem olarak kabul edilmek gerekir. Bu itibarla, vasiyet konusu kazandırmanın işlem kurulduğu andaki akıbetinin belirsizliği nedeniyle açık oransızlık bakımından değerlendirme yapılamaz. Bunun tek istisnasını vasiyet konusunun akıbetinin belirli ve sabit olduğu tedarik ve çeşit vasiyeti oluşturur. Dolayısıyla miras sözleşmesinde oransızlığın belirlenmesi ölüme bağlı tasarruf veya tasarrufların tedarik/çeşit vasiyeti teşkil etmesi halinde mümkündür. Sağlararası kazandırmada kural olarak muhatara yoktur. Bununla birlikte sağlararası edim muhatara içeriyorsa, değerlendirme yapmak yine mümkün olmaz.

Aşırı yararlanmanın miras sözleşmelerinde son derece sınırlı bir uygulama alanı bulabilmesine karşılık, aşırı yararlanmaya başvurulması gerek- 
sinimi hissedilen pek çok durumda sözleşme, kuruluş tarzı itibarıyla ahlaka aykırılık teşkil eder. Bu nedenle miras sözleşmesinin ahlaka aykırılık nedeniyle hükümsüz sayılması olasılı̆̆ mevcuttur. Nihayet, karşı taraftan yararlanma amacıyla hareket eden tarafın sözleşmenin kuruluş sürecinde MK m. 2 'den doğan koruma yükümlülüğünün ihlali sebebiyle culpa in contrahendo sorumluluğunun doğması olasılığı da kuramsal olarak bulunmaktadır. 


\section{KAYNAKÇA}

Acabey, M. Beşir: “Aşırı Yararlanma (TBK m. 28)”, MÜHF-HAD Özel Hukuk Sempozyumu Özel Sayısı (Prof. Dr. Cevdet Yavuz’a Armağan), 2012.

Akbıyık, Cem: Karma Bağışlama ve Miras Hukukundaki Yeri, İstanbul, 1997.

Akbıyık, Cem: Vasiyeti Yerine Getirme Görevlisi, İstanbul, 2012.

Akça, Neslihan: İvazlı Miras Sözleşmeleri, Ankara, 2020 (Gazi Üni. SBE. Doktora Tezi).

Akıncı, Şahin: Borçlar Hukuku Bilgisi, Konya, 2016.

Akkanat, Halil: Ölümün Özel Hukuk İlişkilerine Etkisi, İstanbul, 2004.

Aksoy Dursun, Sanem: "Sözleşmenin İçeriği; Sözleşmelerin Yorumu, Muvazaalı İşlemler”, Prof. Dr. İsmet Sungurbey'e Armağan: Borçlar Hukuku Genel Hükümler Konferansları I, İstanbul, 2014.

Albaş, Hakan: "Mirastan Feragat Sözleşmesi ve Hükümlerine İlişkin Bazı Sorunlar", Dokuz Eylül Üniversitesi Hukuk Fakültesi Dergisi C. 9 (Özel Say1-2007).

Antalya, O. Gökhan/Sağlam, İpek: Miras Hukuku, Ankara, 2019.

Antalya, O. Gökhan: Borçlar Hukuku Genel Hükümler, C. I, İstanbul, 2015 (Borçlar Hukuku).

Antalya, O. Gökhan: Mirastan Feragat Sözleşmesi, İstanbul, 1999 (Feragat).

Arbek, Ömer: Miras Hukukunda Ölüme Bağlı İşlemlerde İrade Serbestisi Sinırlar1 ve Müeyyidesi, Ankara, 2007.

Arpacı, Özge: "Mahkeme Kararları Işı̆̆ında Ölüme Bağlı Tasarruf ile Sağlar Arası Hukuki İşlemlerin Ayrımında Geliştirilen Kriterler”, Ankara Hacı Bayram Veli Üniversitesi Hukuk Fakültesi Dergisi C. 24 S. 1 (2020).

Aslan, Çiğdem Mine: Gabinin Unsurları ve Hukuki Sonuçları, Ankara, 2006.

Ataay, Aytekin: Borçlar Hukukunun Genel Teorisi-Birinci Yarım, İstanbul, 1981.

Ateş, Derya: Borçlar Hukuku Sözleşmelerinde Genel Ahlaka Aykırılık, Ankara, 2007.

Atlan, Hülya: "Miras Sözü Vermeden Doğan Kusurlu Sorumluluk: Culpa In Testando Sorumluluğu", MÜHF-HAD C. 23 S. 2. 
Atlı, Banu: Ölüme Bağlı Tasarrufların Hükümsüzlüğ̈̈ ve Hükümden Düşmesi, Ankara, 2017.

Ayan, Serkan: "Olumlu Miras Sözleşmelerinin İçeriğine Aykırı Hukuki İşlemlere İtiraza Yönelik Medeni Kanun'un 527/II Hükmünün Anlamı", Terazi Hukuk Dergisi, S. 58 Y. 6 (Haziran 2011).

Aydın, Ramazan: "Aşırı Yararlanma (TBK m. 28), Erciyes Üniversitesi Hukuk Fakültesi Dergisi C. 8 S. 1 (Haziran 2013).

Barlas, Nami: "Türk Borçlar Kanunu'nun Gabine İlişkin Yeni Düzenlemesinin Değerlendirilmesi”, Medeni Kanun'un ve Borçlar Kanunu'nun 90. Y1lı Uluslararası Sempozyumu, C. I, Ankara, 2017.

Başoğlu, Başak: "Miras Hukuku Özelinde Haksız Etkileme Kavramı ve Buna Bağlanabilecek Sonuçlar", Galatasaray Üniversitesi Hukuk Fakültesi Dergisi 2018/1.

Baysal, Başak: Sözleşmenin Uyarlanması, İstanbul, 2019.

Belen, Herdem: 6098 sayılı Borçlar Kanunu Genel Hükümler (Kısa Şerh), İstanbul, 2014.

Berki, Şakir: "Türk Medeni Kanununda Mirastan Feragat", Prof. Dr. Mahmut Koloğlu’ya Armağan, Ankara, 1975.

Bıçakçı, Levent: Mirastan Feragat Sözleşmesi, İstanbul, 1999.

Birsen, Kemaleddin: Borçlar Hukuku Dersleri, İstanbul, 1967.

Bucher, Eugen: Schweizerisches Obligationenrecht Allgemeiner Teil ohne Deliktsrecht, Zürih, 1988.

Buz, Vedat: "Gabin Halinde Edimler Arasındaki Aşırı Oransızlığın Giderilerek Sözleşmenin Ayakta Tutulması", Banka ve Ticaret Hukuku Dergisi C. 19 S. 4 (Aralık 1998).

Cansel, Erol/Özel, Çağlar: Borçlar Hukuku Genel Hükümler Cilt-1, Ankara, 2017.

Çakırca, Seda İrem: Aşırı Yararlanma Kavramı, İstanbul, 2015.

Dasser, Felix: Orell Füssli Kommentar (Navigator.ch)- Schweizerisches Obligationenrecht, Zürih, 2016 (Art. 19 OR).

Demirsatan, Barış: Türk Borçlar Kanunu Çerçevesinde Sözleşmenin Haksız Olarak Sona Erdirilmesi, İstanbul, 2019.

Dural, Mustafa/Öz, Turgut: Türk Özel Hukuku Cilt IV Miras Hukuku, İstanbul, 2016.

Dural, Mustafa: Miras Sözleşmeleri, İstanbul, 1980. 
Elbir, Halid Kemal: Türk Pozitif Hukukunda Gabin, İÜHF Doktora Tezi, 1957.

Emmenegger, Susan/Tschentscher, Axel: Berner Kommentar Einleitung, Art. 1-9 ZGB, Bern, 2012.

Engel, Pierre: Traité des obligations en droit suisse, Bern, 1997.

Engin, B. İlkay: Yedek Mirasçılık, İstanbul, 2003.

Eren, Fikret/Yücer Aktürk, İpek: Türk Miras Hukuku, Ankara, 2019.

Eren, Fikret: Borçlar Hukuku Genel Hükümler, Ankara, 2019.

Eren, Fikret: Türk Medeni Hukukunda Ölüme Bağl1 Tasarrufların İptali Davası, Ankara, 1966 (İptal).

Ergüne, M. Serkan: Olumsuz Zarar, İstanbul, 2008.

Ergüne, M. Serkan: Taşınır Mülkiyeti, İstanbul, 2017.

Escher, Arnold: Zürcher Kommentar Art. 457-536 ZGB, Zürih, 1959.

Esener, Turhan/Gündoğdu, Fatih: Borçlar Hukuku I, İstanbul, 2017.

Feyzioğlu, Feyzi N.: Borçlar Hukuku Genel Hükümler, C. I, İstanbul, 1976.

Gauch, Peter/Schluep, Walter R./Schmid, Jörg: Schweizerisches Obligationenrecht Allgemeiner Teil Bd. I, Zürih, 2008.

Gauthier, Jean: Le pacte successoral, Lozan, 1955.

Gönensay, Samim/Birsen, Kemaleddin: Miras Hukuku, İstanbul, 1963.

Guinand, Jean/Stettler, Martin/Leuba, Audrey: Droit de successions, Zürih, 2005.

Gürsoy, Kemal Tahir: Türk Medeni Kanunu Hükümlerine Göre Mal Vasiyeti, Ankara, 1955.

Haddat, Eloïse: Les notions de contrat d'assurance, Paris I Panthéon Sorbonne Üni. Doktora Tezi, Paris, 2017.

Hatemi, Hüseyin: "Miras Sözleşmelerinde Gabin Söz Konusu Olabilir mi?", Prof. Dr. Necip Kocayusufpaşaoğlu için Armağan, Ankara, 2004 (Gabin).

Hatemi, Hüseyin: Miras Hukuku, İstanbul, 2018.

Hausheer, Heinz/Ebi-Müller, Regina E.: Berner Kommentar Band/Nr. I/1, Bern, 2012.

Hirschlehner, Anna: "Culpa in testando - Vertrauenshaftung des Erblassers", Aktuelle Juristische Praxis 2017. 
Hrubesch-Millauer, Stephanie: Handkommentar zum Schweizer Privatrecht- Erbrecht, Zürih, 2016.

Huguenin, Claire: Obligationenrecht-Allgemeiner und Besonderer Teil, Zürih, 2014.

İmre, Zahit: Türk Miras Hukuku, İstanbul, 1978.

İnan, Ali Naim/Ertaş, Şeref/Albaş, Hakan: Türk Medeni Hukuku - Miras Hukuku, İzmir, 2012.

İnan, Ali Naim/Yücel, Özge: Borçlar Hukuku Genel Hükümler, Ankara, 2014.

İnce, Nurten: "Miras Bırakanın Güven Sorumluluğu (Culpa in Testando)", İNÜHFD C. 9 S. 1 (2018).

İşgüzar, Hasan/Demir, Mehmet/Yılmaz, Süleyman: Miras Hukuku, Ankara, 2019.

Karner, Ernst: ABGB Allgemeines Bürgerliches GesetzbuchKurzKommentar zum ABGB, Viyana, 2010 (§1275-1276).

Kılıçoğlu, Ahmet M.: Borçlar Hukuku Genel Hükümler, Ankara, 2018.

Kılıçoğlu, Ahmet M.: Miras Hukuku, Ankara, 2012 (Miras Hukuku).

Kocayusufpaşaoğlu, Necip: Borçlar Hukuku Genel Bölüm I, İstanbul, 2014.

Kocayusufpaşaoğlu, Necip: Miras Hukuku, İstanbul, 1987 (Miras Hukuku).

Köprülü, Bülent: Miras Hukuku Dersleri, İstanbul, 1985.

Kramer, Ernst A.: Berner Kommentar Band/Nr. VI/1/2/1a, Bern, 1991 (Art. 21 OR).

Kuonen, Nicolas: La responsabilité précontractuelle, Zürih, 2007.

Kurşun, Ali Suphi: Aşırı Yararlanma ve Ahlaka Aykırılıkta Taleplerin Yarışması", İstanbul Kültür Üniversitesi Hukuk Fakültesi Dergisi C. 15 S. 2-2 (Temmuz/Ağustos 2016).

Kut, Ahmet: Handkommentar zum Schweizer Privatrech- Obligationenrecht - Allgemeine Bestimmungen, Zürih, 2016 (Art. 21 OR).

Küçükaydın, E. Aslı: "Mirasçı Atama”, İ̈HFM C. 75 S. 1 (2017).

Lange, Knut Werner: Erbrecht, Münih, 2017.

Morin, Anne: Contribution à l'étude des contrats aléatoires, Paris-Dauphine (Paris-IX) Üni. Doktora Tezi, Paris, 1995.

Nomer, Haluk N.: “Aşırı Yararlanma (Gabin) Halinde Sömürülen, Kendisine Tanınan Haklardan Dilediğini Seçmekte Tamamen Serbest 
Midir?”, Prof. Dr. Hasan Erman'a Armağan, İstanbul, 2015 (Aşır1 Yararlanma).

Nomer, Haluk N.: Beklenen Haklar Üzerindeki Tasarrufların Hukuki Sonuçları, İstanbul, 2002.

Nomer, Haluk N.: Borçlar Hukuku Genel Hükümler, İstanbul, 2020.

Oğuzman, M. Kemal/Barlas, Nami: Medeni Hukuk, İstanbul, 2018.

Oğuzman, M. Kemal/Öz, Turgut: Borçlar Hukuku Genel Hükümler, C. I, İstanbul, 2018.

Oğuzman, M. Kemal: Miras Hukuku, İstanbul, 1995.

Okumuş, Selmani: 6098 sayılı Türk Borçlar Kanunu'na Göre Aşırı Yararlanma (Gabin), Ankara, 2015.

Ozanemre Yayla, H. Tolunay: "Ön Vasiyet (Mirasçı Lehine Vasiyet) Kavram1, Ön Vasiyetin Unsurları ve Özellikleri," Ankara Barosu Dergisi, 2017/2.

Özakman, H. Cumhur: Miras Payının Devrine İlişkin Sözleşmeler, İstanbul, 1984.

Öztan, Bilge: Miras Hukuku, Ankara, 2018.

Piotet, Paul: Traité de Droit Privé Suisse T. IV: Droit Successoral, Friburg, 1975.

Reiner, Günter: Derivative Finanzinstrumente im Recht, Baden-Baden, 2002.

Sağlam, İpek: "Haksız Etki”, MÜHF-HAD Özel Sayısı Prof. Dr. Mehmet Somer'in Anısına Armağan, Cilt: 12, Sayı: 1-3, İstanbul, 2006.

Sarı, Suat: "6098 sayılı Türk Borçlar Kanunu'nun Aşırı Yararlanma (Gabin) Hükümlerinde Gerçekleştirdiği Değişiklikler”, Prof. Dr. Mustafa Dural'a Armağan, İstanbul, 2013.

Saymen, Ferit H./Elbir, Halid K.: Türk Borçlar Hukuku Umumi Hükümler, İstanbul, 1958.

Saymen, Ferit Hakkı: “Gabinde İvazlar Arasındaki Nisbetsizlik”, İÜHFM C. 11 S. 3-4 (1945).

Schmidlin, Bruno: Commentaire Romand Code des Obligations I, Basel, 2012 (Art. 21 CO).

Schwarz, Andreas B.: Borçlar Hukuku Dersleri, (Çeviri: Bülent Davran), İstanbul, 1948. 
Schwenzer, Ingeborg: Schweizerisches Obligationenrecht Allgemeiner Teil, Bern, 2016.

Serozan, Rona/Engin, B. İlkay: Miras Hukuku, Ankara, 2014.

Serozan, Rona: "Karşılıklı Sözleşmelerde Baştan Dayatılmış veya Sonradan

Oluşmuş Edimler Arası Dengesizliğin Uyarlama Yoluyla Düzeltilmesi”, Prof. Dr. Kemal Oğuzman'ın Anısına Armağan, İstanbul, 2000 (Dengesizlik).

Serozan, Rona: "Wohin steuert das Erbrecht?", successio 2014.

Serozan, Rona: Sağlararası İşlem Yoluyla Ölüme Bağlı Kazandırma, İstanbul, 1979 (Kazandırma).

Sungur, Hasan Halis: Gabin, İstanbul, 1953.

Tandoğan, Haluk: Özel Borç İlişkileri, C. 1/I, İstanbul, 2010.

Taşatan, Caner: “Türk Medeni Kanunu'na Göre Mirasçı Atama”, İNÜHFD 10(1)-2019.

Tekinay, S. Sulhi/Akman, Sermet/Burcuoğlu, Haluk/Altop, Atilla: Borçlar Hukuku Genel Hükümler, İstanbul, 1993.

Tercier, Pierre/Pichonnaz, Pascal/Develioğlu, H. Murat: Borçlar Hukuku Genel Hükümler, İstanbul, 2016.

Tiftik, Mustafa: "Borç Sözleşmelerinin İrade Sakatlığı Sebebiyle İptalinde Uğranılan Zararın Tazmini”, Erzincan Üniversitesi Hukuk Fakültesi Dergisi C. 10 S. 3-4 (2006).

Topuz, Murat: "Yargıtay Kararları Işı̆ı̆ında Türk Borçlar ve Ticaret Hukukunda Gabin (Aşırı Yararlanma)", MÜHF-HAD, Özel Sayı: Doç. Dr. Mehmet Somer'in Anısına Armağan, 2006.

Tunçomağ, Kenan: Ölünceye Kadar Bakma Akdi, Ankara, 1959.

Tunçomağ, Kenan: Türk Borçlar Hukuku Cilt 1 Genel Hükümler, İstanbul, 1976 (Genel Hükümler).

Tuor, Peter: Berner Kommentar zum schweizerischen Zivilgesetzbuch Band III Das Erbrecht, Bern, 1952.

Turan, Gamze: Ölüme Bağlı Tasarrufların Hükümsüzlüğü, Ankara, 2009.

Uyan, Göktürk: "Miras Sözleşmesinde İki Taraflı Bağlayıcı Kayıtla Vakıf Kurulması", IÜHFM C. 65 S. 2 (2007).

Velidedeoğlu, H. Veldet: Türk Medeni Hukuku, İstanbul, 1963.

Von Tuhr, Andreas/Peter, Hans: Allgemeiner Teil des Schweizerischen Obligationenrechts Band I (mit Supplement), 3. Bask1, Zürih, 1984. 
Weimar, Peter: Berner Kommentar Band/Nr. III/1/1/1- Schweizerisches Zivilgesetzbuch, Das Erbrecht, Die Erben, Die gesetzlichen Erben, Die Verfügungen von Todes wegen, Bern, 2009.

Welser, Rudolf/Zöchling-Jud, Brigitta: Grundriss des bürgerlichen RechtsBand II Schuldrecht Allgemeiner Teil Schuldrecht Besonderer Teil Erbrecht, Viyana, 2015.

Wieling, Hans Josef: Sachenrecht, Heidelberg, 2007.

Yağcı, Kürşad: Cezai Mirasçılıktan Çıkarma, İstanbul, 2013.

Yakupoğlu, S. Derya: Olumlu Miras Sözleşmesi ve Bağlayıcılık Sorunu, Bilkent Üni. Ekonomi ve Sosyal Bilimler Enstitüsü Doktora Tezi, Ankara, 2019.

Yazar Soyadı, Adı: Basler Kommentar Zivilgesetzbuch II Art. 457-977 ZGB, 5. Bas1, Basel, 2015.

Yazar Soyadı, Adı: Commentaire Romand Code Civil II Art. 457-977 CC, Basel, 2016.

Yazar Soyadı, Adı: SHK - Stämpflis Handkommentar - Commentaire du droit des successions, Bern, 2012.

Yıldırım, Mustafa Fadıl: "Beklenen (Açılmamış Bir Terekedeki) Miras Hakkının Devri Sözleşmesi (I), Yargıtay Dergisi C. 21 S. 1-2 (OcakNisan 1995). 


\section{KISALTMALAR}
Al. MK
: Alman Medeni Kanunu
Bkz.
: Bakinız
C. $\quad$ : Cilt
dn. : Dipnotu
HD. : Hukuk Dairesi
HGK. : Hukuk Genel Kurulu
IFM : İsviçre Federal Mahkemesi
IMK : İsviçre Medeni Kanunu
İNÜHFD ： İnönü Üniversitesi Hukuk Fakültesi Dergisi
IÜHFM : İstanbul Üniversitesi Hukuk Fakültesi Mecmuası
JdT : Journal des Tribunaux
Karş. : Karşılaştırınız
Kazancı : Kazancı Çevrimiçi İçtihat Bilgi Bankası
m.
: Madde
MK : Medeni Kanun
MÜHF-HAD : Marmara Üniversitesi Hukuk Fakültesi Hukuk Araştırmaları Dergisi
N. $\quad$ : Kenar/Paragraf Numaras1
s. $\quad$ : Sayfa
S. : Say1
Swisslex : Swisslex Çevrimiçi Hukuk Bilgi Bankası
TBK : Türk Borçlar Kanunu
Yarg. : Yargitay 